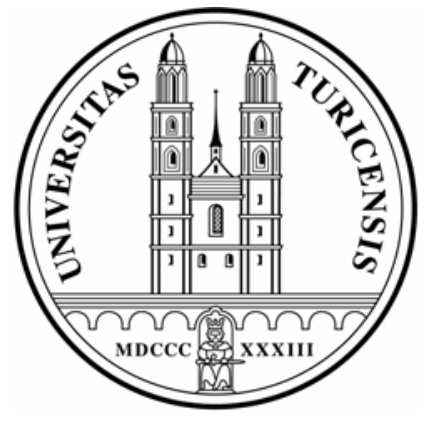

Institute for Empirical Research in Economics

University of Zurich

Working Paper Series

ISSN 1424-0459

Working Paper No. 336

Did Nordic Countries Recognize the Gathering Storm of World War II? Evidence from the Bond Markets

Daniel Waldenström and Bruno S. Frey

October 2007 


\title{
Did Nordic Countries Recognize the Gathering Storm of World War II? Evidence from the Bond Markets ${ }^{*}$
}

\author{
Daniel Waldenström \\ IFN (Research Institute of Industrial Economics) \\ P.O. Box 55665, SE-10215 Stockholm, Sweden \\ Ph: +46-8-6654531, Fax: +46-8-6654599 \\ E-mail: danielw@ifn.se \\ (corresponding author) \\ and \\ Bruno S. Frey \\ Institute for Empirical Research in Economics \\ University of Zurich \\ Winterthurerstrasse 30, CH-8006 Zurich, Switzerland \\ Ph. +41-44-6343730, Fax: +41-44-6343599 \\ E-mail: bsfrey@iew.unizh.ch
}

September 13, 2007

\footnotetext{
* We have received valuable comments from Stephen Broadberry, Tim Guinnane, Magnus Henrekson, Andreas Madestam, Kim Oosterlinck, Jean-Laurent Rosenthal, Ken Snowden, William Summerhill, and two anonymous referees, as well as seminar participants at UCLA, SITE, Stockholm School of Economics, 2003 EHA Annual Meeting, and the CEPR-CREI 2005 conference "War and the Macroeconomy".
} 


\begin{abstract}
This paper analyzes and compares different ways of assessing how people perceived impending threats of war in the past. Conventional Nordic historiography of World War II claims there were few, if any, people in the Nordic countries who perceived a significantly increased threat of war between 1938 and early 1940. At the same time, historical methods face problems when it comes to capturing the often tacitly held beliefs of a large number of people in the past. In this paper, we analyze these assessments by looking at sudden shifts in sovereign debt yields and spreads in the Nordic bond markets at that time. Our results suggest that Nordic contemporaries indeed perceived significant war risk increases around the time of major war-related geopolitical events. While these findings question some - but not all - of standard Nordic World War II historiography, they also demonstrate the value of analyzing historical market prices to reassess the often tacitly held views and opinions of large groups of people in the past.
\end{abstract}

JEL classification: C22, G14, N01, N44.

Keywords: Structural breaks, Sovereign debt, Capital markets, Historiography, Cliometrics, World War II. 


\section{Introduction}

Wars have a huge impact on societies and their citizens, and therefore even the expectation of an outbreak of war could greatly influence people's behavior in various ways, which in turn would affect real economic and political outcomes. Understanding the formation of widely held war risk assessments is important in order to fully comprehend the developments in countries experiencing extremely turbulent times.

At the time of the outbreak of World War II in Europe, the Nordic countries had become a region of central strategic importance. Without Swedish iron ore, the German arms industry would not have lasted many months after the outbreak of the war. The coast of Norway offered an ideal starting point for launching a naval attack on Great Britain, and Finland's dominant position in the Gulf of Finland was a latent problem for the Soviet leaders. All of Europe's superpowers therefore had strong vested interests in keeping their enemies out of the Nordic region, and they all had long-term plans of military interventions in line with these interests. ${ }^{1}$

To what extent did contemporaries in the Nordic countries perceive this mounting threat of war? And did the perceived threats differ, on one hand, for each of the Nordic countries and, on the other, the Nordic region as a whole? Given the significance of public threat perceptions to the overall development of a country, it is not surprising that historians have gone to great lengths to analyze these questions. According to conventional Nordic World War II historiography, there were few, if any, people in the Nordic countries who truly believed in a war in their own countries around the outbreak of World War II. But the historical method used to generate these results is associated with some important methodological problems. Historians primarily rely on in-depth analyses from various written sources, but widely held notions of pending threats of war are typically not systematically documented, and are therefore largely unobservable to historians. Historians are well aware of another potential problem, and that is that they themselves may be influenced by their own social and political context so that their selection and interpretation of historical facts depend on what they conjecture that their readers wish to read. ${ }^{2}$

\footnotetext{
${ }^{1}$ See, e.g., Norborg (1970, pp. 204ff) and Tooze (2006, pp. 380f).

${ }^{2}$ Well-known discussions of these problems, and how to deal with them, are found in Carr (1961) and Ma rwick (1970). For example, winners often write a biased account of the history of wars and, in the case of Denmark, Bryld (2003, pp. 14-29) argues that the official Danish postwar account of the country's resistance movement during World War II is steeped in patriotism as a result of historians giving in to contemporary pressures for a history of legitimization and national unification.
} 
In the present paper, we examine an alternative way of gaining insights into the war threat assessments of people in the past. This method, originally proposed by Willard et al. (1996) in their study of currency price fluctuations around the time of the U.S. Civil War, is based on analyzing sudden changes in yields of government bonds that were traded continuously at the time of the war outbreak, and linking them to major geopolitical prewar events. We argue that this will show if, and when, significant war risk increases occurred, as reflected by market prices. The underlying idea is that wars put extraordinary pressures on countries' fiscal balances and may even provoke governments to repudiate their sovereign debt. An increased risk of war will translate into an increased sovereign risk or, equivalently, higher yields on traded sovereign debt. ${ }^{3}$ Nat urally, the overlap, on one hand, between the general public and, on the other, between traders and investors in government bonds, is not perfect. Still, on the whole, they had access to the same publicly available information and should hence have shared roughly the same threat perceptions at each point in time (see our discussions in Section 3).

Our empirical analysis begins by estimating the widely held threat assessments from shifts in Nordic sovereign yields and spreads traded on the Nordic bond markets at that time. We then compare these market-based estimates with the corresponding ones in conventional historiography, which we retrieve from reading a large number of writings by well-known and reputed Nordic World War II historians. The final result is a comparative analysis, which not only conveys information about whether the Nordic political and military preparations for an enemy attack were in line with the general views about external threats of war, but also addresses the important question of whether conventional historiography is robust to alternative assessments of certain historical phenomena. ${ }^{4}$

We use data on newly assembled sovereign yields from the financial markets in Copenhagen, Oslo, Helsinki and Stockholm, quoted in 1938-1940. ${ }^{5}$ These data are unique in that they come from a country (Sweden), which was never directly engaged in the war, and hence not subject to the kind of specific regulations of pricing and trading that was com-

\footnotetext{
${ }^{3}$ Naturally, this also requires minor changes in other standard bond yield determinants, such as the coupon rate, the time to maturity, the tax status of cash flows, redemption clauses and the discount rate. Although these were mostly constant, we estimated the breaks using yield spreads (subtracting the Swedish yields) and hence canceling out market-specific determinants. These estimations produced essentially the same results and are available from the authors upon request.

${ }^{4}$ Nordic historians agree today that the Nordic countries, possibly with the exception of Finland, were not sufficiently prepared in terms of mobilization of armed forces around the outbreak of World War II (e.g., Åhslund, 1982; Olsson, 1977, p. 12; Gram, 1986, pp. 18f; Skodvin, 1991, p. 309). At the same time, many historians argue that this was a deliberate strategy on the part of the Nordic governments, since they believed a low level of armaments to be a credible signal of peaceful intentions (e.g., Lidegaard, 2005, p. 152 on the case for Denmark).

${ }^{5}$ Note that the fifth Nordic country, Iceland, is excluded, because of a lack of Icelandic go vernment bond data.
} 
mon among belligerent countries. Moreover, the Stockholm market listed bonds from the other Nordic countries and we observe both domestic and foreign sovereign yields in our analysis. The econometric method is structural breaks estimations in the yields and spreads, using the well-known method of Bai and Perron $(1998,2003)$, which selects breaks endogenously, using only the time series properties of the yields and no prior historical information. As explained above, these breaks reflect the contemporaneously updated sovereign risk assessments of the historical financial market actors. When coinciding with important political or military pre-war events, we argue that a link is established between changes in sovereign yields and shifts in widely perceived threats of war.

The study relates to a growing literature that uses financial market data to analyze the effect of political and institutional change. In the groundbreaking analysis of Willard et al. (1996), events that took place during the U.S. civil war are analyzed, based on their impact on the market for "greenbacks", a special currency issued by the Union. Following their approach, Brown and Burdekin (2000) and Oosterlinck and Weidenmier (2007) study the turning points of the U.S. Civil War from the perspective of British and Dutch investors respectively. In a study of the evolution of market-assessed war risks associated with the great European powers between 1848 and 1914, Ferguson (2006) shows that, contrary to the traditional views among political historians, the market actors in London did not anticipate the outbreak of World War I. While Ferguson's analysis is close in spirit to ours, and therefore serves as a useful benchmark to our findings, our studies differ in several ways, including temporal and geographical focus, methodologies used and the fact that we analyze assessments of both domestic and foreign actors for all countries studied.

There have been a number of studies with particular focus on the developments around World War II. Frey and Kucher $(2000,2001)$ analyze how the events surrounding the war affected domestic and foreign government bond prices at the Zurich stock exchange. They find that the stock exchange consistently reflected many of the historically important events, such as the German annexation of Austria, the outbreak of the war, the German defeat at Stalingrad and the Yalta conference. Oosterlinck (2003) compares prices of Vichy bonds with pre-war French bonds, Brown and Burdekin (2002) study German bonds traded in Britain, and Frey and Waldenström (2004) compare simultaneously traded Belgian and German bonds in Switzerland and Sweden. In an analysis of the more recent U.S. war in Iraq in 2003, Rigobon and Sack (2005) find that the U.S. financial markets capitalized on a considerable war risk premium in several assets just before the outbreak of war. Looking at the same war, Wolfers and Zitzewitz (2005) find that war probabilities derived from prices at prediction markets (electronic markets for securities with payoffs contingent on, e.g., war outbreaks) were highly consistent with war-related news. 
The rest of our paper is organized as follows. Section 2 outlines conventional Nordic historiography on assessed war risks around World War II and some methodological problems with it. Section 3 discusses the dataset and institutional features of the Nordic bond markets. Section 4 presents the econometric methodology and Section 5 gives the main results. In Section 6, we present a number of robustness checks. Section 7 summarizes and concludes.

\section{Nordic historiography on World War II threats and its problems}

This section describes how "conventional" Nordic World War II historiography has portrayed people's war threat assessments during 1938-1940. In doing this, we refer explicitly to writings of nineteen well-known and reputed Danish, Finnish, Norwegian and Swedish historians. ${ }^{6}$ Naturally, we cannot claim to provide a complete coverage of the large historical literature on this particular topic. Yet, by explicitly referring to, and even citing as many works as possible, we hope to minimize any problems with interpretation and selection. The choice of only analyzing the writings of Nordic historian is based on two premises. First, given that most of the historical sources are in Nordic languages, they should be particularly well suited to characterize the past assessments of the Nordic citizens. Second, the Nordic historians correspond the closest to the Nordic bondholders, whose assessments we derive from bond market prices.

There are some important methodological problems associated with the historical approach to describe sentiments among the general public in past times. For example, since historians mainly cite written sources in their work, they run the risk of missing many of the public opinions that were (and still are) mostly tacit and almost never explicitly expressed or documented in writing. Hence, they are practically unobservable to historians. Another, and perhaps more severe, problem with the historical method is that historians, and possibly war historians in particular, might be influenced by their own postwar political and social context when selecting and interpreting the historical facts at hand. Wellknown historians (see, e.g., Carr, 1961 or Marwick, 1970) have noted this potential sample selection bias before, but it nevertheless prevails as an imminent methodological problem, not least in some of the official Nordic World War II historiography. ${ }^{7}$

\footnotetext{
${ }^{6}$ It should be noted that, besides these nineteen researchers, the works of at least twice as many Nordic hi storians have been scanned, but their writings say nothing about the public sentiments at this time. One comprehensive listing of the Nordic World War II literature is Nøkleby (2003). Although the Finnish historian, Max Jakobson, lacks a formal academic background, his works are widely cited and used by professional historians in all Nordic countries.

${ }^{7}$ For example, Bryld (2001) describes the Danish historiography of World War II as a "history of legitim ization" (p. 14). He states further: "The official history of the occupation was made up in 1945, a story of
} 
Denmark: Historians agree that the Danes felt relatively safe from getting involved in any of the war activities taking place on the European continent, and that the German invasion of Denmark on April 9, 1940, came as a complete surprise. The Danes were, of course, well aware of their geographical proximity to Germany. When Denmark, as the only Scandinavian country, signed a non-aggression pact with Germany in mid-1939, this was regarded as "ensuring peace and stability" (Nissen, 1988, p. 353f). ${ }^{8}$ There is surprisingly little said about the reactions to the outbreak of war in Poland and Finland. The overall level of uncertainty among the public seems to have increased somewhat after the New Year speech of the Danish Prime Minister in January 1940, in which he stated that, if it were to happen, Denmark would hardly be able to withstand a foreign invasion. People were at first infuriated by this defeatist attitude, but Wendt (1966, pp. 41f) states that "All their worries disappeared entirely" after all the political parties in Parliament openly declared that the Danish neutrality was not threatened. One historian, Lidegaard (2005, p. 152), claims that Danish politicians were confident their passive policy would minimize the risk of war: "the less Denmark did to attract [Hitler's] attention the better". When the German invasion finally occurred on April 9, 1940, Gram (1986, p. 15) describes it as being totally unexpected: "With the greater part of Norwegian and Danish political and public concerns focused on the British laying of mines, the German strategic plan for command of Norway - and the occupation of Denmark that would require - succeeded in catching everybody by surprise."

Finland: Most Finnish historians describe the Soviet Union as being perceived as a potential threat by the Finns in the 1930s. There was even open mutual distrust between the two countries' politicians (Zetterberg, 1991, p. 56). Yet, Jakobson (1961, p. 99) writes: “there was no sense of immediate danger in Finland during the beautiful late summer of August and September 1939". Interestingly, the Swedish viewpoint was more pessimistic: "The German-Russo pact [publicly announced on August 23] placed Finland in an awkward position: Everybody could see that it offered Russia its best chance to re-conquer Finland since 1920" (Thulstrup, 1950, p. 8). A bit later, the Finns also perceived an increased Soviet threat. Jakobson (1961, p. 139) writes that, although Foreign Minister Paasikivi believed, in mid-November, that Stalin would leave Finland in peace, "The majority, however, held a different view of Stalin's intentions". Finally, it is not clear if the Finns really

political and pragmatic art which satisfied the needs for political unity and ethical consistency of the elites [...] and the majority of the population. [...] The main element of this story telling was patriotism." (p. 29). In the case of Norway, Skodvin (1991, pp. 309f) describes that there were many postwar forces interested in influencing war history so that "their own people" came out as favorably as possible in the descriptions.

${ }^{8}$ Note that all citations of Nordic historians (except for Jakobson, 1961, and Zetterberg, 1991) are our own translations from the original Nordic languages. 
anticipated the Soviet attack on November 30 or not. On one hand, Finland was fully mobilized already in early October but, on the other, the government started to send troops home from the front in mid-November. Perhaps this can be explained by evidence later found by historians, which says that "most diplomatic observers" in Finland and in Moscow at the time perceived that "the Soviet Union would not try to enforce its claims on Finland or Romania by force of arms" (Jakobson, 1961, p. 142).

Norway: Historians agree that, of all Northerners, the Norwegians felt the most safe from becoming involved in a war on the European continent. Therefore, the German invasion in April 1940 is described as coming as a complete surprise. As in the case of Denmark, very little is said about the public's reaction to the wars on the continent and in Finland. Not even the Altmark incident on February 16, 1940 is described as having affected the Norwegians. During this incident, British troops boarded a German destroyer in Norwegian waters. This launched a fierce German protest against Norway, which resulted in a sharp Norwegian protest against Britain (Skodvin, 1991, pp. 38f). Finally, the German invasion came as a complete surprise. According to Bull (1979, pp. 342f), its "surprise tactics were successful", which was evidenced by the fact that many of the Oslo residents were "woken up in the night by the sirens warning of an airborne attack, and were annoyed, as they believed that it was yet another siren practice". Jensen (1965, p. 113) also writes: "On the basis of what everyone knew [at the time], the situation was so serious that it now seems unimaginable that we did not react any differently than we did. It only shows how deeply rooted the belief had generally become among the Norwegians, that we could manage to keep out of the conflict. The parliament and government were representatives of a view that was general."

Sweden: Most - but not all - of the Swedish historians describe the Swedes as having felt safe from being attacked in 1939-1940. For example, Åberg (1992, p. 522) states: "In the beginning of the war, none of the governments in Sweden, Norway and Denmark seems to have worried about a German attack on Scandinavia". Carlgren (1989, p. 150) claims: "there is a striking contrast between the confidence shown [after the outbreak of World War II] and the widespread popular worries that followed the outbreak of World War I". By contrast, Johansson (1982, p. 138) presents a somewhat different picture by arguing that the Finnish war made the Swedes aware of the external military threats: "When World War broke out, the Nordic countries did not seem threatened. Many people regarded the Pact in Moscow as assuring peace in the Baltic region. [...] The war between Finland and the Soviet Union, however, was a severe blow that stunned Sweden." He continues: "There was general agreement among the overwhelming majority of the population that Sweden must use each day that it was still at peace to prepare its military defense. The 
overall sentiment was that Sweden enjoyed a respite from the gallows which had to be exploited" (Johansson, 1982, p. 139). In his important work on the ideological underpinnings of the Swedish newspaper columnists during 1938-1939, Åmark (1973, pp. 155ff) argues that there was public awareness of a military threat to Sweden, but that it was relatively small. For example, Åmark states: "there was a general consensus that Sweden faced little risk of war as long as there was no war in the rest of Europe" and, similarly, that: "An outbreak of war in Europe was hence a necessary precondition, but not sufficient reason for an attack on Sweden" (p. 155). An interesting example of how contemporary ideology could influence written statements is that the editorialists often "deliberately exaggerated the risk of war in order to pursue their own [politico-ideological] agenda in their foreign and defense policy" (p. 160). After Germany's invasion of Denmark and Norway, Sweden began to send home their already limited number of troops which, according to Norborg (1981, pp. 249ff), signifies a firm belief that the Swedish government did not fear being drawn into war activities at that time. ${ }^{9}$ On ba lance, it is fair to say that historians would describe the Swedish threat assessments as largely nonexistent during most of this period, perhaps with the exception of the time of the Finnish-Soviet war (November 30, 1939 March 12, 1940).

\section{Data and institutional setting}

Our main dataset consists of secondary market yields of government bonds of the four Nordic countries: Denmark, Finland, Norway and Sweden. These yields to maturity are computed from a newly assembled database, containing the daily and weekly prices bid at the bond markets in Copenhagen, Helsinki, Oslo and Stockholm between January 1938 and December 1940. We restrict our analysis to the end of the interwar era in order to avoid capturing numerous other (mostly unobservable) events driving sovereign yield shifts that are not necessarily related to the immediate risk of war. A supplementary dataset, with weekly U.S. yields on long-term government bonds and 3-5 year Treasury notes, as well as monthly yields on British and Swiss long-term government bonds, was also collected for the robustness analysis in Section 6. Detailed information on these individual bond loans and their sources is listed in Table 1 . The slight variation in data coverage across markets is primarily due to general difficulty in finding good data sources, but, in the case of Helsinki Stock Exchange, all bond trading was stopped as of October 11, 1939.

\footnotetext{
${ }^{9}$ Two much more imminent threats of war to Sweden, according to Norborg (1981, p. 255) and Johansson (2002), were the "Midsummer Crisis" in June 1941, when the Swedish government considered refusing the Germans to ship troops across Swedish territory, and the "February Crisis" in February 1942, when the Swedes sent large numbers of troops to the Norwegian border in order to meet an expected German invasion based on cracked German secret messages.
} 
For the quoted bond prices to be of sufficiently high quality and consistency, it is necessary to have well functioning underlying market institutions, as well as active trading in the analyzed bonds. Historical bond markets have been shown to be highly sophisticated relative to today's market places in terms of information dissemination and market thickness. For example, Mauro et al. (2006) convincingly argue that this was indeed the case for the sovereign debt market in London during 1870-1914. Since no such previous investigations exist for the Nordic sovereign debt markets of the late 1930s, we have collected some evidence suggesting that these markets functioned relatively well in order for their prices to hold up to meaningful scrutiny. Specifically, a sample of daily trading volumes from the Stockholm Stock Exchange price lists during March, June, September and December in 1938 and 1940 shows that there was trading in all four Nordic government bonds at all times, except for Norwegian bonds which were sparsely traded after April 1940. These volumes are lower bounds of the true trading, since the traditionally most important secondary bond market is the over-the-counter (OTC) market. Our estimates of the extent of the Swedish OTC market suggest that the total bond trading was between three and five times larger than the exchange-based trading. ${ }^{10}$ As regards the bond markets in the other Nordic countries, there seems to have been regular pricing and trading in domestic government bonds throughout the period of analysis. ${ }^{11}$

Despite indications of the existence of regular bond trading activity in all market places examined in this study, there are a few instances where the level of trading seems to have been unusually low. One such instance is the Helsinki market for Finnish bonds in 1939, where the day-to-day changes in the quoted bond price (and yield) were zero, with a constant price level as a result (see Figure 4 below). While, at times, there may have been a lack of new relevant information to capitalize Finnish government bonds, it is more likely that this particular price pattern indicates an insufficient level of trading, even though we have not found any indications of this in the contemporary media (Hufvudstadsbladet) or in writings about the Helsinki stock exchange (e.g., Tiderman, 1962). Another instance of problematic data are the two periods of time on the Stockholm market when there are missing values in the Finnish yields (in December 1939) and the Norwegian yields (in April-May 1940). Since our econometric methodology requires the analyzed series to be

\footnotetext{
${ }^{10}$ OTC trading volumes are estimated using securities transaction tax receipts, which by law were to be $\mathrm{r}$ eported for all transfers, regardless of the market place. Data only exist for the first half-year of 1926 in a survey by the Swedish Banking Inspection reported in a government proposal (Prop. 1927:56 p. 13) and for 1948 onwards from the Banking Inspection's recurrent official publication Uppgifter om bankerna samt uppgifter om fondkommissionärerna och fondbörs.

${ }^{11}$ For a detailed analysis of the trading of Danish bonds in Copenhagen, see Waldenström (2006, Table 1). Aggregate annual bond trading volumes at the exchanges in Oslo (Ramm, 1969) and Helsinki (Tiderman, 1962) suggest that there was continuous trading, and it is likely that a great deal of this trading took place in the domestic government debt.
} 
continuous, we have linearly interpolated all instances of missing values. Having missing values could indicate that there are severe problems with, for example, extraordinarily low levels of trading or with reporting quoted prices. By consequently using bid prices instead of sell prices, we at least reduce the risk of having individual traders influencing prices. More importantly, most of the gaps appear after the outbreak of war in the respective Nordic countries, but since our analytical focus lies primarily on the behavior of pre-war yields, this problem has no important effect on the core findings of our study.

Government interventions in the bond markets constitute another potential problem concerning the data used. Such non-market influences surely occurred, especially since borrowing governments are usually quite interested in keeping market interest rates, i.e., their own cost of capital, as low as possible. Available anecdotal evidence from the Danish and Stockholm markets suggests, however, that these initiatives were relatively few and probably had a limited long-run effect on market yields. ${ }^{12}$ Since our analysis of sovereign yield changes focuses on very large and lasting yield shifts, we do not expect any government-led market operations to significantly influence the main empirical results.

The identity of the bond market actors is another institutional feature of great relevance to a study like ours. Although we would like the overlap between, on one hand, the general public and, on the other, the traders and investors in government bond to be perfect, in reality it is not. For example, only some of the people held government bonds. Evidence from Sweden on individual bond ownership exists in the Census of 1945 and the government debt registries at the National Debt Office for the years 1939-1945. The Census shows that there were about 345,000 adults in 1945 owning mainly government-issued bonds. When subtracting the public debt issued after our period of analysis (which ended in 1940) and the Census year 1945, however, that number should be reduced by at least half, if not more. ${ }^{13}$ The overlap is then more plausible with regard to the way that the ge neral public and the bond investors acted on the same, publicly available information. Hence their views and expectations about the future should be roughly the same. ${ }^{14}$ Finally,

\footnotetext{
12 Kock (1943) argues that the Swedish Riksbank had almost no effect on market interest rates in 1939-1940. The Danish central bank, Nationalbanken, only increased its bond portfolio marginally between June and December 1939, and even decreased its bond portfolio during the most critical period, December 1939 and June 1940 (Svendsen, 1968, p. 16). Furthermore, the monetary policy issues addressed by the $N a$ tionalbanken in the early war years were more concerned with how to prevent interest rates from falling too much in the light of the abundant liquidity levels in the Danish economy. In other words, the Danish central bank worked to raise, and not to reduce, market interest rates during the war period.

${ }^{13}$ For data on bondholding in 1945, see Statistics Sweden (1951, Table I, p. 31* and Table K, p. 35*). For data on the new issues of public debt during 1940-45, see Nygren (1945, pp. 177-198).

${ }^{14}$ In an interesting in-depth analysis of the sovereign risk analyses by market actors at Credit Lyonnais in the period 1870-1913, Flandreau (2003) argues that the information sets of public and large financial institutions were not necessarily identical, as the latter at times strategically disseminated information to earn profits for themselves.
} 
there may be some differences in risk aversion between the traders and investors we observe and the rest of the population who owned no financial assets. ${ }^{15}$ The difference should not be large, given that government bonds are generally looked at as low-risk securities. If anything, the recorded shifts in sovereign yields (and spreads) can be seen as lower bounds of true population responses to perceived war risk.

\section{Empirical methodology}

Our basic methodology is to link major shifts in sovereign yields with simultaneous geopolitical events and thereby get a notion of changes in widely held war threat assessments as reflected in bond markets. We focus on shifts rather than levels of the yields, since there are many influences on a sovereign bond's yield level, whereas a large and, in particular, sudden shift more likely reflects a shock to the continuous update sovereign riskassessments made by market actors.

We employ a standard econometric methodology to test for and estimate unknown multiple structural breaks in univariate time series, developed by Bai and Perron $(1998,2003){ }^{16}$ Among the many advantages of using this methodology is that it does not require any prior information about the existence or the timing of the breaks, as they are estimated endogenously, only using information contained in the time series. This feature is not only important for the asymptotic consistency of the estimated breaks (Perron, 2006), but it also makes sure that the breaks are not selected on purpose by the researcher in order to match the contemporaneous political developments they are to be evaluated against.

We estimate the breaks by fitting the following system of linear regressions:

$$
y_{t}=c_{j}+{ }_{-}, \quad t=T_{j-1}+1, \ldots, T_{j} .
$$

where subscript $j(j=1, \ldots, m+1)$ denotes segments separated by $m$ structural breaks, $y_{t}$ is a country's nominal sovereign yield at time $t$ expressed in basis points, $c_{j}$ is an estimated intercept (the average yield in each segment) and $\_t$ is a white noise error term. ${ }^{17}$ The method begins by testing for the existence of breaks using two types of Wald tests. If these tests indicate that breaks exist, the method continues to estimate their exact number and then their size. One important parameter to decide before running the procedure is the

\footnotetext{
${ }^{15}$ Standard models in economic and financial psychology show that people who hold or trade risky assets are less risk averse than those who do not (see, e.g., Wärneryd, 2001).

${ }^{16}$ For details of the method's inferential setup, we refer the reader to the papers by Bai and Perron (1998, 2003). All estimations use the GAUSS program available from Pierre Perron's web page.

${ }^{17} \mathrm{We}$ follow the convention of using $T_{0}=1$ and $T_{m+1}=T$ (total length of sequence).
} 
shortest segment length allowed for the breaks to be referred to as "structural". We follow the conventions and require breaks to be at least ten percent of the total sequence length (denoted as " $T$ " in Table 1). Specifically, the segments are about 20 days long in the daily series and 16 weeks in the weekly series. ${ }^{18}$

Our motivation for using a relatively simple model, as in equation (1), is that this mean model produces intuitive and easily interpreted estimates of the structural breaks; the break size, $j^{-}{ }^{j-1}$, is the number of basis points by which the yields increase or decrease.

Two potentially problematic modeling issues arise. First, most high-frequency financial variables exhibit some degree of persistence, which is not fully accounted for in equation (1). The Bai and Perron methodology has an apparatus for dealing with a wide range of error distributions, however, and it alleviates most modeling issues of this nature. Moreover, simulations by Paye and Timmerman (2006) suggest that persistence has a limited effect on the ability of Bai and Perron's method to consistently pick the correct break points, especially when break magnitudes are large (which they are in our analysis).

A second important modeling issue is that nominal sovereign yields also pick up influences from factors other than the default risk, predominantly various macroeconomic fluctuations, such as inflation or market interest rates and expectations about them. We address this factor in a number of robustness tests reported in Section 6. Specifically, we replaced the yields in equation (1) with yield spreads, calculated as the Nordic yields divided by U.S., British, Swiss and Swedish yields (for the non-Swedish Nordic countries) in a variety of ways. The yield spreads should, in principle, cancel out all common macroeconomic influences and leave the sovereign risk as the sole determinant. The results are basically identical with the main results of the paper, which again shows our method and findings to be satisfactorily robust.

Finally, what is the expected impact of a war on a country's sovereign yields and how should one interpret the magnitudes of a structural break in terms of changes in the perceived threat of war? Unfortunately, there exist no clear-cut answers to these questions in either asset pricing theory or financial history. In principle, borrowing countries balance their expected default costs (reputational losses resulting in costlier future borrowing) with their benefits (retained cash that is not paid out to lenders). Wars may alter both costs and

\footnotetext{
${ }^{18}$ Ideally, one would have liked the shortest segments to be the same across all markets, i.e., that we used shorter segments in the weekly Stockholm series. But in order for there to a sufficient number of observations within each segment, we had to settle for 10 percent. Technically, we set the trimming parameter $\pi$ to be 0.10 (10 percent), i.e., that $T_{j} \geq \pi_{-} T$. Bai and Perron (2005) recommend having at least 18 observations in each segment for the calculation of variance-covariance matrices.
} 
benefits in complex ways due to many factors, including fiscal status, credit history, debt contract design (e.g., existence of gold clauses) etc. In an historical exposé, Suter (1992, pp. 61-83) finds that belligerent countries have been both defaulters and non-defaulters. Mauro et al. (2006, ch. 5) show that news of war increased emerging market yields in London during $1870-1914$ by an average 300 basis points (which is almost a doubling of yields).

There are attempts in the previous applied literature to compute variants of what can be called an "assessed war probability", using observable market prices. For example, Wolfers and Zitzewitz (2005) analyze contracts in prediction markets that pay off when some specified event (for example, war) occurs and their prices can thereby be interpreted as the probability of that event occurring. A parallel concept is proposed by Merrick (2001), who uses a cash flow model of sovereign default from which a "default probability" is derived by comparing net present values of bonds under different repayment alternatives (defaults, partial defaults and no defaults). In our paper, we use the fact that we actually observe market yields both before and after the realization of war. The market yield recorded immediately after the war outbreak is then interpreted as the yield when war is known for certain. By dividing the pre-war yields recorded right before the war outbreak, with the war yield level recorded just after the outbreak, we attain a ratio that is the closest we can get with our data to measuring a widely held "assessed war probability" in the period leading up to the war. To give an example of how we use this concept, consider a ratio between the yields immediately before and after the war outbreak of, say, 0.7. That ratio would then be interpreted as an "assessed war probability" of 70 percent, i.e., that market actors before the war considered the likelihood of an outbreak of war to be 70 percent. $^{19}$

\section{Results and comparative analysis}

\subsection{Structural breaks in Nordic sovereign yields}

Table 2 presents the estimated structural breaks in the Nordic sovereign yields before the outbreak of World War II in the respective countries. Observing the Danish yields quoted in Copenhagen (Figures 1 and 2), we see that they contain several positive breaks at the time of major war events, which clearly indicate that Danes perceived an increased threat of war well before the German invasion in early April 1940. The first two breaks, amounting to a combined increase of 120 basis points, occurred around the time of the

\footnotetext{
${ }^{19}$ As a disclaimer, it should be noted that this "assessed war probability" concept assumes that war ou tbreaks always influence countries' ability to repay the sovereign debt. While this is plausible in the context of the present study, for sufficiently large and developed countries going to war against much smaller countries, the fiscal consequences of the war would be marginal and the sovereign yield-based war probability concept hence less informative.
} 
outbreak of World War II. The third break in mid-February 1940 coincided with the Altmark incident off the Norwegian coast (discussed above). Looking at Danish breaks in Stockholm (Figure 3), we see similar, but more marked indications of perceived war threats in 1939. There is a very small, and seemingly politically insignificant break in late 1938, but then there is a notable break in late March 1939, shortly after the German annexation of Czechoslovakia. A third break occurred in late August 1939, exactly at the same time as the first break in Copenhagen. The fourth break is recorded in early December 1939, right after the Soviet attack on Finland. This break increased Danish yields by as much as 215 basis points. Finally, the German invasion of Denmark on April 9, 1940 gave rise to a significant break of +361 basis points, but with an initial peak at $+1,900$ basis points! These results show that the traders in Denmark and Sweden clearly perceived an increased war threat on Denmark well ahead of the German invasion. The invasion peak in Stockholm, however, indicates that the Swedish investors still believed that continuation of peace was more likely than outbreak of war in Denmark. ${ }^{20}$

Let us now consider the Finnish government bonds at home and abroad. The Finnish yields in Helsinki (Figure 4) exhibit two very small, but unimportant, breaks recorded during February-March 1939. A third, larger break on September 6, of +62 basis points, suggests that the outbreak of war on the continent was clearly perceived as affecting Finland in a negative way. Since the Helsinki Stock Exchange closed down all bond trading on October 11, we cannot tell from the yields how the Finns reacted to the continued development, but the closure of the stock exchange alone indicates growing fears of substantially increased political turbulence. The Finnish yields in Stockholm (Figure 5) contain three structural breaks, the first one in early September 1939, i.e., at the same time as in Helsinki, only much larger, of +862 basis points. The second break was in early December, i.e., after the Soviet attack on Finland, which increased the yields by an additional 2,083 basis points! The third break occurred in mid-March 1940, immediately after the Soviet-Finnish truce, and interestingly it was by $-1,298$ basis points. In other words, while both the Finns and Swedes interpreted the German-Russo anti-aggression pact and the outbreak of war in Poland as considerably increased external threats to Finland, the actual outbreak of war in Finland further increased the sovereign risk (in Sweden).

We now turn to the Norwegian government bonds. The Norwegian yields in Oslo (Figure 6) experienced five structural breaks. Of these, the first four in early September, midOctober, early December 1939, and late January 1940 were significant increases of 132 basis points in total. While the September and December breaks are clearly associated

\footnotetext{
${ }^{20}$ The "assessed war probability", calculated as the Stockholm yields right before the war, divided by the tip of the yield peak right after the war outbreak, is 40 percent for Denmark $(750 \mathrm{bp} / 1,150 \mathrm{bp}=0.395)$.
} 
with war events in Poland and Finland, the other two are less obviously connected to the war developments. The fifth break occurred in mid-March 1940, directly in relation to the announced truce in Finland and, interestingly, it was a fall of 55 basis points, indicating a lower perceived threat after this peaceful event. As for the Norwegian yields in Stockholm (Figure 7), they portray a much more homogenous picture. The first break in early September 1939, showing a 201 basis points increase, and the second break of +176 basis points in late December clearly indicate increased war threats to Norway, as perceived by traders in Sweden. Then there was a third break in April 1930, recorded just after the German invasion, measuring +333 basis points, indicating that the eventuality of war was not entirely capitalized by the Swedish market actors. Later in 1940, there was a fourth break of -243 basis points, which most likely signaled the resolved uncertainty about the effects of the German occupation on Norway's economy and, perhaps, even its status as a sovereign nation.

Finally, the Swedish yields recorded in Stockholm (Figure 8) experienced five structural breaks between 1938 and 1940. Three of these were significant yield increases, occurring right at the time of several major war events: the outbreak of war in early September 1939 ( +66 basis points), the Finnish-Soviet war in December 1939 ( +44 basis points) and the German invasion of Denmark and Norway in early April 1940 ( +15 basis points). An interesting observation is that the closer the war gets to Scandinavia, the smaller the yield increases become. This could signal that Swedes regarded the risk of an attack on Sweden as being independent of the risk of attacks on the other Nordic countries. Given the vast importance of the Swedish iron ore exports to the German war industry in particular, such a conjecture may actually have been plausible at the time.

A general finding of these estimations is the interesting distribution of responses to the events across geographical borders. While foreign and domestic traders react almost identically in time to the same major political events, the magnitude of their reactions in terms of basis point changes differ by a factor of between five and fifteen. The MolotovRibbentrop Pact, for example, boosted the Danish government yields by 51 basis points in Copenhagen and by 136 basis points in Stockholm. Similarly, the Soviet invasion of Finland raised Norwegian sovereign yields by 48 basis points in Oslo and by 176 basis points in Stockholm. The reason for this heterogeneity has been studied by Waldenström (2006), who looks at the specific case of the Danish sovereign debt traded in Copenhagen and Stockholm in the late 1930s and the entire 1940s. The single most important explanation 
for this discrepancy is that governments discriminate against foreign investors, mainly because of political power concerns. ${ }^{21}$

\subsection{Comparing the views of historians and markets}

We now go on to compare the estimated pre-war threat assessments made by historians (discussed in Section 2) and bond markets (discussed in Section 5.1). Because neither approach is free of methodological and data-related problems, this exercise is not about any version being "right" or "wrong" or "better" or "worse". Rather, we wish to shed light on whether they differ at all and, if so, why and in what way. In Table 3, we summarize the findings from previous sections by periodically classifying the assessed threat levels by country and methodological approach. A first result is that there is agreement in the Nordic citizens perceived almost no external threat before late August 1939. The Danish yields rose somewhat in March of that year, but the substantial yield increases came only after the Molotov-Ribbentrop Pact and the German attack on Poland. The lack of major threat increases after the German annexations of Austria and Czechoslovakia in 1938 and 1939 also indicates that the Nordic people did not compare themselves to the Austrians or Czechs in terms of foreign policy relations with Germany.

The most significant overall result from the comparison is the discrepancy in perceived threats between the two versions. In short, the financial markets signal substantially higher war risk expectations than historians do. For example, whereas historians report that the Danes and Norwegians felt pretty secure up until the German invasion, the markets display a number of dramatic yield increases following some of the most important warrelated events: the German-Russo Pact, the outbreak of World War II and the war between Finland and the Soviet Union, as well as some minor events in early 1940. In the case of the Finns, both the Finnish and Swedish financial markets reflect significant war threats after the German-Russo Pact and the outbreak of war, whereas historians suggest there were none. Interestingly, not even the Finnish political and military leaders, who were arguably better informed than the Finnish people, perceived a higher risk of war in line with the bond markets before the Soviet attack. Our historical outline in Section 2 shows that, while the Finnish people in October 1939 started feeling distinctly uneasy about Soviet intentions after having observed the Soviet annexations of the Baltic States, the Finnish government continued to put their trust in the benevolence of Stalin and even withdrew troops from the front in late November.

\footnotetext{
${ }^{21}$ Competing hypotheses rejected by Waldenström (2006) are local government (or central bank) interfe rence in bond market to keep yields low, institutional differences in market regulations and microstructure, and different degrees of risk aversion across the national markets.
} 
There are, however, several points of agreement between the historians and the markets. One such instance is the fact that the Norwegian yields in Oslo actually decreased after the announcement of the Moscow truce in March 1940, which was interpreted as lowering the risk of war on Norwegian soil. It should be noted that the Swedes did not reach the same conclusions, given that the Norwegian yields in Stockholm remained at their relatively high pre-invasion level throughout March. Another example of concurrence is that the realization of wars in Finland, Denmark and Norway produced yield peaks in the respective countries' bonds traded in Stockholm. If anything, this indicates that there was no one who fully anticipated a war in line with some of the historians' claims. Looking at the "assessed war probabilities" (see the discussion in Section 4) for the countries, based on the yields in Stockholm, the probability of war in Denmark was 40 percent (750 bp / 1,150 bp $=0.395)$, in Finland about 34 percent $(1,100 \mathrm{bp} / 3,200 \mathrm{bp}=0.344)$ and in Norway about 54 percent $(700 \mathrm{bp} / 1,300 \mathrm{bp}=0.538)$.

\section{Robustness analysis}

As we highlighted in Section 4, when discussing the estimation of structural breaks in sovereign yields, there is a risk that these mean-shifts may be partly, or wholly, driven by an unobserved simultaneous shock to some nominal macroeconomic variable (e.g., inflation or market interest rates) which, in turn, would have a first-order impact on the nominal bond yield studied by us. In order to control for such exogenous effects, we rerun the structural breaks analysis, using sovereign yield spreads on the left hand side. The yield spreads are computed by subtracting from each Nordic yield an equivalent government yield of different reference countries as follows:

$$
y_{\text {Nordic country }, t}-y_{\text {Reference country }, t}=c_{j}+_{-}, \quad t=T_{j-1}+1, \ldots, T_{j} .
$$

Yield spreads should, at least in principle, cancel out all common macroeconomic influences and leave the spread solely determined by the sovereign risk. However, any common sovereign risks to the countries included in the spread measure are also eliminated, even though we would have liked to capture them in our breaks. For example, an increased risk of war directed specifically at all neutral European countries would not be observed in Nordic spreads over, say, Swiss sovereign yields.

If we find that the breaks estimated when using spreads differ from those using yields in terms of a) the occurrence and timing of break dates and b) the magnitudes of the estimated breaks, this would cast doubt on the robustness of our previous findings. In particular, if the spreads do not contain any statistically significant positive pre-war breaks around the time of the major geopolitical shocks, which is our prime identifier of increased 
war threat assessments on the part of the general public, our core results would be more or less rejected.

\subsection{Nordic spreads in the Stockholm market}

We begin by estimating structural breaks in weekly yield spreads, using Nordic yields in Stockholm and one of three reference yields: U.S. long-term (12 year) government bonds, U.S. short-term (3-5 year) Treasury notes, and the Swedish government yields. ${ }^{22}$ Obv iously, the latter only permits robustness tests of the breaks in Danish, Finnish and Norwegian yields. The spreads over the Swedish yields are conceptually preferred, since they are denominated in the same currency and thereby best suited for separating out macroeconomic shocks to nominal returns. While the U.S. yields only do this for globally common trends or shocks, they are still relatively useful as reference yields, since both the U.S. and the Nordic countries were similar in other respects: neither were in the war at the time and yet both had national economies (and hence the forces driving nominal fluctuations) that were highly affected by the wartime turbulence.

Table 4 presents the findings of the robustness break analysis. Overall, the pre-war breaks in the basic yield analysis also appear in the spread analysis. There are even some earlier minor sovereign risk increases picked up in the spread breaks, which would strengthen the previous conclusion of assessed threat increases well before the war. The differences in timing of the estimated breaks ("Datediff.") are mostly small (0 or 1 weeks), except in the case of Sweden, where the timing is more affected, but still well within the pre-war period. The size difference of the breaks ("Sizediff.") is somewhat larger, with spreads mostly generating smaller breaks. In no instance, however, does the size switch sign. Altogether, these results point to an overall robustness of the baseline findings in our previous yield analysis.

\subsection{Danish and Norwegian spreads in the Copenhagen and Oslo markets}

In a second set of robustness tests, we analyze Danish and Norwegian spreads recorded in their home markets, subtracting one of the following reference yields: British $2.5 \%$ consol yields, Swiss confederate state and railway bonds, the U.S. long-term government yield, and the Swedish yield. Due to data availability, we only have monthly series, and therefore we focus on spread changes over some specific pre-war time periods. Finland is excluded because of its lack of data on domestic yields after early October 1939.

\footnotetext{
${ }^{22}$ It should be noted that the U.S. weekly yields are weekly averages calculated on Fridays, whereas the Nordic yields in Stockholm are quoted on the Tuesday of the corresponding week.
} 
Figures 9 and 10 show the Danish and Norwegian spreads. Looking at spread changes between the early pre-war period (1938-early 1939) and the late pre-war period (1939/early 1940), Danish spreads over U.S. and British yields increased markedly whereas they increased only moderately, and even decreased, over Swiss and Swedish yields, respectively. Over the same time period, all Norwegian yield spreads increased, three of them substantially and one of them (the Swedish) moderately. These results indicate that the significant pre-war threats observed in our basic break analysis remain in most yield spread definitions. Interestingly, the spreads over U.S. and British yields consequently increased more during 1939 than the Swiss spreads and especially the Swedish spreads did. The causes of this heterogeneity are not obvious: Sweden and Switzerland were the only neutral countries; Britain was the only one to enter the war in 1939; Sweden was much more integrated economically with Denmark and Norway than any of the other three reference countries; the U.S. is the only non-European country etc. Regardless, the main message is that the spreads contain much of the pre-war threats previously found.

\section{Concluding remarks}

Did the people in the Nordic countries expect that their own countries would be drawn into war activities during the turbulent years 1938-1940? This paper examines and compares two different empirical methodologies and their answers to this question. In "conventional" Nordic historical writing, it is argued that there were few, if any, people in these countries who really believed in an attack on their countries. In the other approach, we present new evidence based on detecting large shifts in Nordic government bond yields that coincided with important war events, which together reflect changes in war risks that were assessed in real time by contemporaries.

Our main finding is that there are several instances of disagreement between the two interpretations of history. While historians claim that the Nordic people felt safe until the autumn of 1939 (in the case of Finland), the winter of 1939 (in the case of Sweden) and early April of 1940 (in the cases of Denmark and Norway), the prices of these countries' sovereign debt fell considerably several months before these conjectured dates. In most cases, the yield shifts were direct responses to major war-related events, such as the announcement of the Molotov-Ribbentrop Pact in late August 1939 or the Soviet attack on Finland in late November of that year.

We also find, however, points of agreement between historians and markets. For example, Norwegian yields in Oslo dropped after the truce between Finland and the Soviet Union, which indicates widely held sentiments of reassurance in line with the standard historiography. The peaks in all Nordic government yields traded in Stockholm at the outbreak of 
war also indicate that market traders had not fully anticipated the wars, but only regarded them as likely to some degree (we propose assessed war probabilities in the range of $35 \%-54 \%)$.

\section{References}

Åberg, A. (1992), Vår svenska historia, Natur och Kultur, Stockholm.

Åberg, K. (1973), Makt eller moral. Svensk offentlig debatt om internationell politik och svensk utrikes- och försvarspolitik 1938-1939, Allmänna Förlaget, Stockholm.

Affärsvärlden (various issues), Stockholm.

Aftenposten (various issues), Oslo.

Åhslund, B. (1982), "Det militärpolitiska läget vid krigsutbrottet 1939”, in Carl-Axel Wangel (ed.), Sveriges militära beredskap 1939-1945, Militärhistoriska förlaget, Köping.

Bai, Jushan, Perron, P. (1998), "Estimating and Testing Linear Models with Multiple Structural Changes", Econometrica 66(1), 47-78.

Bai, Jushan, Perron, P. (2003), "Multiple Structural Change Models: A Simulation Analysis", Journal of Econometrics 18(1), 1-22.

Berlingske Tidende (various issues), Copenhagen.

Brown, W. O., Burdekin, R. C. K. (2000), "Turning Points in the U.S. Civil War: A British Perspective", Journal of Economic History 60(1), 655-669.

Brown, W. O., Burdekin, R. C. K. (2002), "German Debt Traded in London during the Second World War: A British Perspective on Hitler", Economica 69(276), 655-669.

Bryld, C. (2001), Kampen om historien. Brug og misbrug af historien siden Murens fald, Roskilde Universitetsforlag, Fredriksberg.

Bull, E. (1979) “Klassekamp og felleskap 1920-1945”, in K. Mykland (ed) Norges historie. Bind 13, J. W. Cappelens forlag, Oslo.

Federal Reserve Board (1943), Banking and Monetary Statistics, downloaded at http://fraser.stlouisfed.org/publications/bms/ (3/10/2007).

Carlgren, W. M. (1989), "Den stora överraskningen”, in B. Hugemark (ed), Stormvarning. Sverige inför andra världskriget, Probus, Stockholm.

Carr, E. H. (1961), What Is History?, MacMillan, London.

Ferguson, N. (2006), "Political Risk and the International Bond Market Between the 1848 Revolution and the Outbreak of the First World War", Economic History Review 59(1), 70-112.

Finanstidende (various issues), Copenhagen.

Flandreau, M. (2003), "Caveat Emptor: Coping with Sovereign Risk Under the International Gold Standard, 1871-1913", in M. Flandreau, C.-L. Holtfrerich and H. James (eds.) International Financial History in the Twentieth Century, Cambridge: Cambridge University Press. 
Frey, B. S., Kucher, M. (2000), "History as Reflected in Capital Markets. The Case of World War II", Journal of Economic History 60(3), 468-496.

Frey, B. S., Kucher, M. (2001), "Wars and Markets. How Bond Values Reflect the Second World War", Economica 68(271), 317-333.

Frey B. S., Waldenström, D. (2004), "Markets Work in Wars: The Zurich and Stockholm Markets during World War II", Financial History Review 11(2), 51-67.

Gram, G. (1986), Norske tilstande. Norge under 2. verdenskrig, Odense Universitetsforlag, Odense.

Hufvudstadsbladet (various issues), Helsinki.

Jakobson, M. (1961), The Diplomacy of the Winter War. An Account of the Russo-Finnish War, 1939-1940, Harvard University Press, Cambridge, Mass.

Jensen, M. (1965), Norges historie. Fra 1905 til våre dager, Universitetsforlaget, Kristiansand

Johansson, A. W. (1982), "Det finska exemplets inverkan på svensk försvarsvilja”, in C.A. Wangel (ed.), Sveriges militära beredskap 1939-1945, Militärhistoriska förlaget, Köping.

Johansson, A. W. (2002), "I skuggan av operation Barbarossa. Attityder och stämningar 1940/41" in B. Hugemark, ed., I orkanens öga. 1941 - osäker neutralitet, Svenskt Militärhistoriskt Bibliotek, Luleå.

Kock, K. (1943), "Swedish Economic Policy during the War", Review of Economic Studies 10(2), 75-80.

League of Nations, Economic and Financial Section, Statistical Yearbook of the League of Nations. Currency Statistics, Prices and Public Finance, Geneva, downloaded at: http://www.library.northwestern.edu/govinfo/collections/league/stat.html (3/10/2007)

Lidegaard, B. (2005), Kampen om Danmark 1933-1945, Gyldendal, Copenhagen.

Marwick, A. (1970), The Nature of History, Macmillan, London.

Mauro, P., Sussman, S., Yafeh, Y. (2006), Emerging Markets and Financial Globalization. Sovereign Bond Spreads in 1870-1913 and Today, Oxford University Press, Oxford.

Merrick, J. J., Jr (2001), “Crisis Dynamics of Implied Default Recovery Ratios: Evidence from Russia and Argentina”, Journal of Banking \& Finance 25(10), 1921-1939.

Morgenbladet (various issues), Oslo.

Nissen, H. S. (1988), "Udenrigspolitik 1933-1940" in N. F. Cristianson, Karl Christian Lammers and Henrik S. Nissen Danmarks historie. Bind 7. Tiden 1914-1945, Gyldendal, Copenhagen.

Nøkleby, B. (2003), "Bibliographical Survey - Scandinavia”, Mimeo, European Science Foundation.

Norborg, L.-A. (1970), Grannländernas historia, Almqvist \& Wiksell, Arlöv.

Norborg, L.-A. (1981), 170 år i Sverige. Svensk samhällsutveckling 1809-1979, Berlings, Arlöv. 
Nygren, I. (1974), Svensk kreditmarknad under freds- och beredskapstid 1935-1945, Department of Economic History, Gothenburg University: Gothenburg.

Nygren, I. (1979), Riksgäldskontoret 1939-1945. Statens upplåning för beredskap och räntestabilisering, Dept. of Economic History, Gothenburg University.

Olsson, U. (1977), The Creation of Modern Arms Industry: Sweden, 1939-1974, Dept. of Economic History, University of Gothenburg.

Oosterlinck, K. (2003), “The Bond Market and the Legitimacy of Vichy France”, Explorations in Economic History 40(3), 326-344.

Oosterlinck, K, Weidenmier, M. (2007), "Did Johnny Reb Have a Fighting Chance? A Probabilistic Assessment From European Financial Markets", Mimeo, Claremont McKenna College.

Paye, B. S., Timmermann, A. (2006), "Instability of Return Prediction Models", Journal of Empirical Finance 13(3), 274-315.

Perron, P. (2006), "Dealing with Structural Breaks", in K. Patterson and T. C. Mills, Palgrave Handbook of Econometrics, Volume 1: Econometric Theory, London, Palgrave MacMillan.

Ramm, H. (1969), I neringslivets tjenste, Chrisitiania Börs 1819-1924, Oslo Börs, 1925-1969, Merkur, Drammen.

Rigobon, R., Sack, B. (2005), “The Effect of War Risk on U.S. Financial Markets", Journal of Banking and Finance 29(7), 1769-1789.

Skodvin, M. (1979), "Den politiske utvikling”, in K. Molin, H. S. Nissen, M. Skodvin, H. Soikkanen and J. Weibull, eds, Norden under andra världskriget, Th. Laursens Bogtrykkeri A/S, Tønder.

Skodvin, M. (1991), Norsk historie 1939-1945. Krig og okkupasjon, Det Norske Samlaget, Oslo

Statistics Sweden (1951), Folkräkningen den 31 december 1945. VIII:2. Partiella undersökningar (bottensamplingen). Behandlar delar av statistiken över förmögenhet. Sveriges Officiella Statistik: Folkmängden och dess förändringar, K.L. Beckmans Boktryckeri: Stockholm

Suter, C. (1992), Debt Cycles in the World-Economy. Foreign Loans, Financial Crises, and Debt Settlements, 1820-1990, Westview Press, Boulder.

Svendsen, K. E., Hansen, S. A., Olsen, E., Hoffmeyer, E. (1968) Dansk pengehistorie 1700-1960. Bind 3: Bilag, Odense: Danmarks Nationalbank.

Swedish Bankers Association, Swedish Bond Catalogue [Svensk obligationsbok], Stockholm, various years.

Swedish Riksbank (1942), Statistical Yearbook of 1942, Sveriges Riksbank, Stockholm.

Tiderman, F. (1962), Helsingfors Fondbörs, 1937-1962, Centraltryckeriet, Helsingfors.

Thulstrup, Å. (1950), Svensk utrikespolitik under andra världskriget, Albert Bonniers förlag, Stockholm.

Tooze, A. (2006), The Wages of Destruction. The Making and Breaking of the Nazi Economy, Viking, London. 
Waldenström, D. (2006), "Why Does Sovereign Risk Differ for Domestic and Foreign Investors? Evidence from Scandinavia, 1938-1948", IFN Working Paper No. 677, Research Institute of Industrial Economics.

Weibull, J. (1991), "The Politics of the Scandinavian States under the Threat of Hitler", in R. Bohn (Ed.), Neutralität und totalitäre Aggression, Franz Steiner Verlag, Stuttgart.

Wendt, F. (1966), “Bescettelse og Atomtid 1939-1965”, in Johan Danstrup och Hal Koch (ed) Danmarks historie. Bind 14, Politikens forlag, Copenhagen.

Willard, K. L., Guinnane, T. W., Rosen, H. S. (1996), “Turning Points in the Civil War: Views from the Greenback Market", American Economic Review 86(4), 1001-1018.

Wolfers, J., Zitzewitz, E. (2005), "Using Markets to Inform Policy: The Case of the Iraq War", Mimeo, Wharton School of Business.

Wärneryd, K. E. (2001), Stock-market psychology: How people value and trade stocks, Edward Elgar, Cheltenham.

Zetterberg, S. (1991), Finland after 1917, Otava, Helsinki. 
Table 1: Nordic government bond loans analyzed in the study.

\begin{tabular}{|c|c|c|c|c|c|c|}
\hline Bond, loan period, coupon & Freq. & $\mathrm{T}$ & Ave. & Curr. & Analysis period & Source \\
\hline \multicolumn{7}{|l|}{ Stockholm market: } \\
\hline Danish gov., 1936-56, 4\% & Weekly & 157 & 550 & SEK & $1 / 4 / 38-12 / 31 / 40$ & Affärsvärlden \\
\hline Finnish gov., 1934-44, 5\% & Weekly & 157 & 1160 & SEK & $1 / 4 / 38-12 / 31 / 40$ & Affärsvärlden \\
\hline Norwegian gov., $1934-59,4 \%$ & Weekly & 157 & 580 & SEK & $1 / 4 / 38-12 / 31 / 40$ & Affärsvärlden \\
\hline Swedish gov., consol, $3 \%$ & Weekly & 157 & 330 & SEK & $1 / 4 / 38-12 / 31 / 40$ & Affärsvärlden \\
\hline \multicolumn{7}{|l|}{ Copenhagen market: } \\
\hline Danish gov., 1934-59, 4\% & Weekly & 78 & 5460 & DKK & $10 / 1 / 38-4 / 5 / 40$ & Finanstidende \\
\hline Danish gov., 1934-59, 4\% & Daily & 189 & 4930 & DKK & $7 / 3 / 39-4 / 8 / 40$ & $\begin{array}{l}\text { Berglinske } \\
\text { Tidende }\end{array}$ \\
\hline \multicolumn{7}{|l|}{ Oslo market: } \\
\hline Norwegian gov., 1937-68, 4.5\% & Daily & 212 & 510 & NOK & $8 / 2 / 39-4 / 8 / 40$ & $\begin{array}{l}\text { Morgenbladet, } \\
\text { Aftenposten }\end{array}$ \\
\hline \multicolumn{7}{|l|}{ Helsinki market: } \\
\hline Finnish gov., 1935-60, 5\% & Daily & 238 & 510 & FIM & $1 / 3 / 39-10 / 10 / 39$ & $\begin{array}{l}\text { Hufvudstads- } \\
\text { bladet }\end{array}$ \\
\hline \multicolumn{7}{|l|}{ U.S. market: } \\
\hline U.S. gov., 1938-40, 12-yrs & Weekly & 157 & 237 & USD & $1 / 4 / 38-12 / 31 / 40$ & Fed. Reserve \\
\hline U.S. T-Note, $1938-40,3-5$-yrs & Weekly & 157 & 63 & USD & $1 / 4 / 38-12 / 31 / 40$ & Fed. Reserve \\
\hline $\begin{array}{l}\text { British market: } \\
\text { British consol, 1938-40, 2.5\% }\end{array}$ & Daily & 36 & 352 & GBP & $1 / 38-12 / 40$ & L.o.N..$^{c}$ \\
\hline $\begin{array}{l}\text { Swiss market: } \\
\text { Swiss gov., 1938-40. }\end{array}$ & Monthly & 36 & 372 & SWF & $1 / 38-12 / 40$ & L.o.N. ${ }^{c}$ \\
\hline
\end{tabular}

Note: "Freq." denotes trading frequency, "T" is the number of observations, "Ave." is the average mean level of the series used, "Curr." is the denomination of the bond loan, "Period" is the period for which each bond is analyzed, restricted either by the time focus of the study or data availability.

${ }^{a}$ Federal Reserve Board (1943), Table 129: Bond yields, by type of security, weekly, 1934-1941.

${ }^{\mathrm{b}}$ Federal Reserve Board (1943), Table 121: Short-term open-market rates in New York City, weekly, 1934-1941.

.c League of Nations, Tables 109 (1938-39) and 105 (1940-41): Percentage Yields of Bonds. 
Table 2: Structural breaks in Nordic sovereign yields. Stockholm market, 1938-1940.

\begin{tabular}{|c|c|c|c|c|}
\hline $\begin{array}{l}\text { Country, } \\
\text { Break No. }\end{array}$ & Break date & $\begin{array}{l}\text { Confidence } \\
\text { interval } \\
\text { (neriods) }\end{array}$ & $\begin{array}{c}\text { Break size } \\
\text { (basis points) }\end{array}$ & Contemporaneous war event \\
\hline
\end{tabular}

\begin{tabular}{ccccl}
\hline Denmark & \multicolumn{5}{c}{ Copenhagen market, Daily series, Jul.1939-Apr.1940 } \\
1 & $8 / 25 / 1939$ & {$[-2,+1]$} & +51 & German-Soviet anti-aggression pact \\
2 & $9 / 26 / 1939$ & {$[-4,+1]$} & +71 & Outbreak of World War II \\
3 & $2 / 14 / 1940$ & {$[-1,+6]$} & +54 & Altmark incident (?) \\
\multicolumn{5}{c}{ Copenhagen market, Weekly series, Oct.1938-Apr.1940 } \\
1 & $9 / 22 / 1939$ & {$[-1,+1]$} & +120 & Outbreak of World War II \\
2 & $2 / 16 / 1940$ & {$[-1,+2]$} & +54 & Altmark incident (?) \\
\multicolumn{5}{c}{ Stockholm market, Weekly series, Jan. $1938-$ Dec.1940 } \\
1 & $12 / 13 / 1938$ & {$[-6,+6]$} & +13 & \\
2 & $3 / 28 / 1939$ & {$[-19,+1]$} & +40 & Germany annexes Czechoslovakia \\
3 & $8 / 22 / 1939$ & {$[-6,+2]$} & +136 & German-Soviet anti-aggression pact \\
4 & $12 / 5 / 1939$ & {$[-2,+3]$} & +215 & Soviet Union attacks Finland \\
5 & $4 / 9 / 1940$ & {$[-38,+1]$} & +361 & Germany invades Denmark \\
\hline
\end{tabular}

Finland Helsinki market, Daily series, Jan.1939-Oct.1939

$\begin{array}{ccccc}1 & 2 / 2 / 1939 & {[-4,+1]} & -5 & \\ 2 & 3 / 30 / 1939 & {[-27,+1]} & +6 & \\ 3 & 9 / 6 / 1939 & {[-1,+1]} & +62 & \text { Outbreak of World War II }\end{array}$

Stockholm market, Weekly series, Jan.1938-Dec.1940

\begin{tabular}{ccccl}
1 & $9 / 5 / 1939$ & {$[-6,+6]$} & +864 & Outbreak of World War II \\
2 & $12 / 9 / 1939$ & {$[-19,+1]$} & $+2,083$ & Soviet Union attacks Finland \\
3 & $4 / 2 / 1940$ & {$[-6,+2]$} & $-1,298$ & Finnish-Soviet peace treaty \\
\hline
\end{tabular}

\begin{tabular}{ccccl} 
Norway & \multicolumn{5}{c}{ Oslo market, Daily series, Aug. 1939-Apr.1940 } \\
1 & $9 / 8 / 1939$ & {$[-3,0]$} & +38 & Outbreak of World War II \\
2 & $10 / 16 / 1939$ & {$[-2,+13]$} & +17 & \\
3 & $12 / 11 / 1939$ & {$[-1,+1]$} & +48 & Soviet Union attacks Finland \\
4 & $1 / 29 / 1939$ & {$[-1,+3]$} & +29 & \\
5 & $3 / 13 / 1939$ & {$[-1,+1]$} & -55 & Finnish-Soviet peace treaty \\
\multicolumn{5}{c}{ Stockholm market, Weekly series, Jan. $1938-$ Dec. 1940} \\
1 & $9 / 5 / 1939$ & {$[-1,+2]$} & +201 & Outbreak of World War II \\
2 & $12 / 26 / 1939$ & {$[-1,+1]$} & +176 & Soviet Union attacks Finland \\
3 & $4 / 30 / 1940$ & {$[-1,+1]$} & +333 & Germany invades Norway \\
4 & $9 / 10 / 1940$ & {$[-1,+2]$} & -243 & Norwegian resistance ends (Aug.) \\
\hline
\end{tabular}

Sweden Stockholm market, Weekly series, Jan.1938-Dec.1940

\begin{tabular}{ccccl}
1 & $4 / 18 / 1939$ & {$[-26,+1]$} & +8 & \\
2 & $9 / 12 / 1939$ & {$[-2,+1]$} & +60 & Outbreak of World War II \\
3 & $12 / 26 / 1939$ & {$[-1,+3]$} & +44 & Soviet Union attacks Finland \\
4 & $4 / 9 / 1940$ & {$[-15,+3]$} & +15 & Germany attacks Denmark/Norway \\
5 & $7 / 30 / 1940$ & {$[-1,+2]$} & -49 & \\
\hline
\end{tabular}

Note: The table shows the number of breaks selected by the procedure of Bai and Perron $(1998,2003)$, their 95\% confidence interval in brackets showing the number of periods (days or weeks) surrounding the break date, the size of the break in numbers of basis points (the difference between average yields in the segments before and after the break), and a political or military event coinciding with the break. Additional estimation results that are not presented in the table include the $\operatorname{Sup} F_{T}\left(\_\mid 0\right)$ and $\max _{1 \geq \_L} \operatorname{Sup} F_{T}\left(\_\mid 0\right)$ tests for existence of breaks, and the sequential $\operatorname{Sup} F_{T}\left(+\left.1\right|_{-}\right)$test for the number of breaks. These are available upon request. 
Table 3: Nordic government bond loans analyzed in the study.

\begin{tabular}{|c|c|c|c|c|}
\hline \multirow[t]{2}{*}{ Country } & \multirow[t]{2}{*}{ Time period } & \multicolumn{2}{|c|}{$\begin{array}{l}\text { Public pre-war threat assessments } \\
\text { according to... }\end{array}$} & \multirow[b]{2}{*}{ Agreement? } \\
\hline & & Historians $^{\mathrm{a}}$ & Bond markets $^{\mathrm{b}}$ & \\
\hline \multirow{3}{*}{ Denmark } & - Mar. 1939 & None & None & Yes \\
\hline & Apr. 1939 - Aug. 25, 1939 & None & Some & No \\
\hline & Aug. 25, 1939 - Apr. 1940 & None & Some/Large & No \\
\hline \multirow{3}{*}{ Finland } & - Aug. 23, 1939 & None & None & Yes \\
\hline & Aug. 23, 1939 - Sep. 1939 & None & Some/Large & No \\
\hline & Oct. 1939 - Nov. 1939 & Some & Large & No \\
\hline \multirow{3}{*}{ Norway } & - Aug. 1939 & None & None & Yes \\
\hline & Sep. 1939 - Mar. 13, 1940 & None & Some/Large & No \\
\hline & Mar. 13, 1940 - Apr. 9, 1940 & None & Some & No \\
\hline \multirow{3}{*}{ Sweden } & 1938 - Aug. 30, 1939 & None & None & Yes \\
\hline & Sep. 1, 1939 - Nov. 30, 1939 & None & Some & No \\
\hline & Dec. 1, 1939 - & Some & Some & Yes \\
\hline
\end{tabular}

Note: When the market-based assessment says "Some/Large", this means that the increase in domestic yields posed a lesser threat ("Some") than the increase in foreign yields ("Large") in response to a political event.

${ }^{a}$ Based on the historical writing outlined in Section 2.

${ }^{\mathrm{b}}$ Based on structural break estimates in Table 3 . 
Table 4: Robustness analysis: Structural breaks in Nordic spreads. Stockholm market, 1938-1940.

\begin{tabular}{|c|c|c|c|c|c|c|c|c|c|c|c|c|c|}
\hline \multicolumn{2}{|c|}{ Bond yield } & \multicolumn{4}{|c|}{ Spread over Swedish bond yield } & \multicolumn{4}{|c|}{ Spread over U.S. bond yield } & \multicolumn{4}{|c|}{ Spread over U.S. Treasury Notes } \\
\hline Date & Size & Date & Datediff. & Size & Sizediff. & Date & Datediff. & Size & Sizediff. & Date & Datediff. & Size & Sizediff. \\
\hline \multicolumn{14}{|l|}{ Denmark } \\
\hline & & & & & & $4 / 12 / 38$ & & 25 & & $4 / 12 / 38$ & & 40 & \\
\hline $12 / 6 / 38$ & 13 & & & & & & & & & $12 / 6 / 38$ & 0 & 54 & 41 \\
\hline $3 / 21 / 39$ & 40 & $3 / 21 / 39$ & 0 & 80 & 40 & $3 / 14 / 39$ & 1 & 77 & 37 & & & & \\
\hline \multirow[t]{2}{*}{ 8/15/39 } & 249 & & & & & 8/15/39 & 0 & 229 & -20 & $8 / 8 / 39$ & 1 & 252 & 3 \\
\hline & & $11 / 28 / 39$ & & 212 & & & & & & & & & \\
\hline $4 / 2 / 40$ & 458 & $4 / 9 / 40$ & 1 & 373 & -85 & $4 / 2 / 40$ & 0 & 481 & 23 & $4 / 2 / 40$ & 0 & 473 & 15 \\
\hline \multicolumn{14}{|l|}{ Finland } \\
\hline & & $1 / 24 / 39$ & & -18 & & & & & & $4 / 12 / 38$ & & 43 & \\
\hline $8 / 29 / 39$ & 864 & $8 / 15 / 39$ & 2 & 711 & -153 & 8/29/39 & 0 & 852 & -11 & $8 / 15 / 39$ & 2 & 739 & -124 \\
\hline $12 / 12 / 39$ & 2083 & $12 / 5 / 39$ & 1 & 1197 & -886 & $12 / 12 / 39$ & 0 & 2109 & 26 & $12 / 5 / 39$ & 1 & 1270 & -813 \\
\hline $3 / 26 / 40$ & -1298 & & & & & $3 / 26 / 40$ & 0 & -1287 & & & & & \\
\hline \multicolumn{14}{|l|}{ Norway } \\
\hline & & & & & & & & & & $4 / 12 / 38$ & & 46 & \\
\hline & & $3 / 7 / 39$ & & 24 & & $3 / 21 / 39$ & & 65 & & $3 / 21 / 39$ & & 105 & \\
\hline 8/29/39 & 201 & $8 / 29 / 39$ & 0 & 123 & -79 & $8 / 29 / 39$ & 0 & 144 & -57 & & & & \\
\hline $12 / 19 / 39$ & 176 & $12 / 26 / 39$ & 1 & 134 & -42 & $12 / 19 / 39$ & 0 & 202 & 26 & $12 / 5 / 39$ & 1 & 281 & 105 \\
\hline $4 / 23 / 40$ & 333 & $4 / 30 / 40$ & 1 & 328 & -4 & $4 / 23 / 40$ & 0 & 329 & -4 & $4 / 16 / 40$ & 1 & 321 & -12 \\
\hline $9 / 3 / 40$ & 243 & $8 / 27 / 40$ & 1 & 269 & 26 & $9 / 3 / 40$ & 0 & 272 & 30 & $8 / 27 / 40$ & 1 & 273 & 31 \\
\hline \multicolumn{14}{|l|}{ Sweden } \\
\hline & & & & & & $9 / 20 / 38$ & & 15 & & $4 / 12 / 38$ & & 34 & \\
\hline 4/11/39 & 8 & & & & & 4/11/39 & 0 & 35 & 27 & $2 / 21 / 39$ & 7 & 28 & 19 \\
\hline 9/5/39 & 60 & & & & & & & & & $10 / 10 / 39$ & 5 & 74 & 14 \\
\hline $12 / 19 / 39$ & 44 & & & & & $11 / 14 / 39$ & 10 & 76 & 32 & $1 / 23 / 40$ & 5 & 48 & 5 \\
\hline $4 / 2 / 40$ & 15 & & & & & $2 / 27 / 40$ & 5 & 33 & 18 & & & & \\
\hline $7 / 23 / 40$ & -49 & & & & & $6 / 11 / 40$ & 6 & -29 & & $5 / 21 / 40$ & 9 & -42 & 7 \\
\hline
\end{tabular}


Figure 1: Danish sovereign yields and structural breaks. Copenhagen market (daily data).

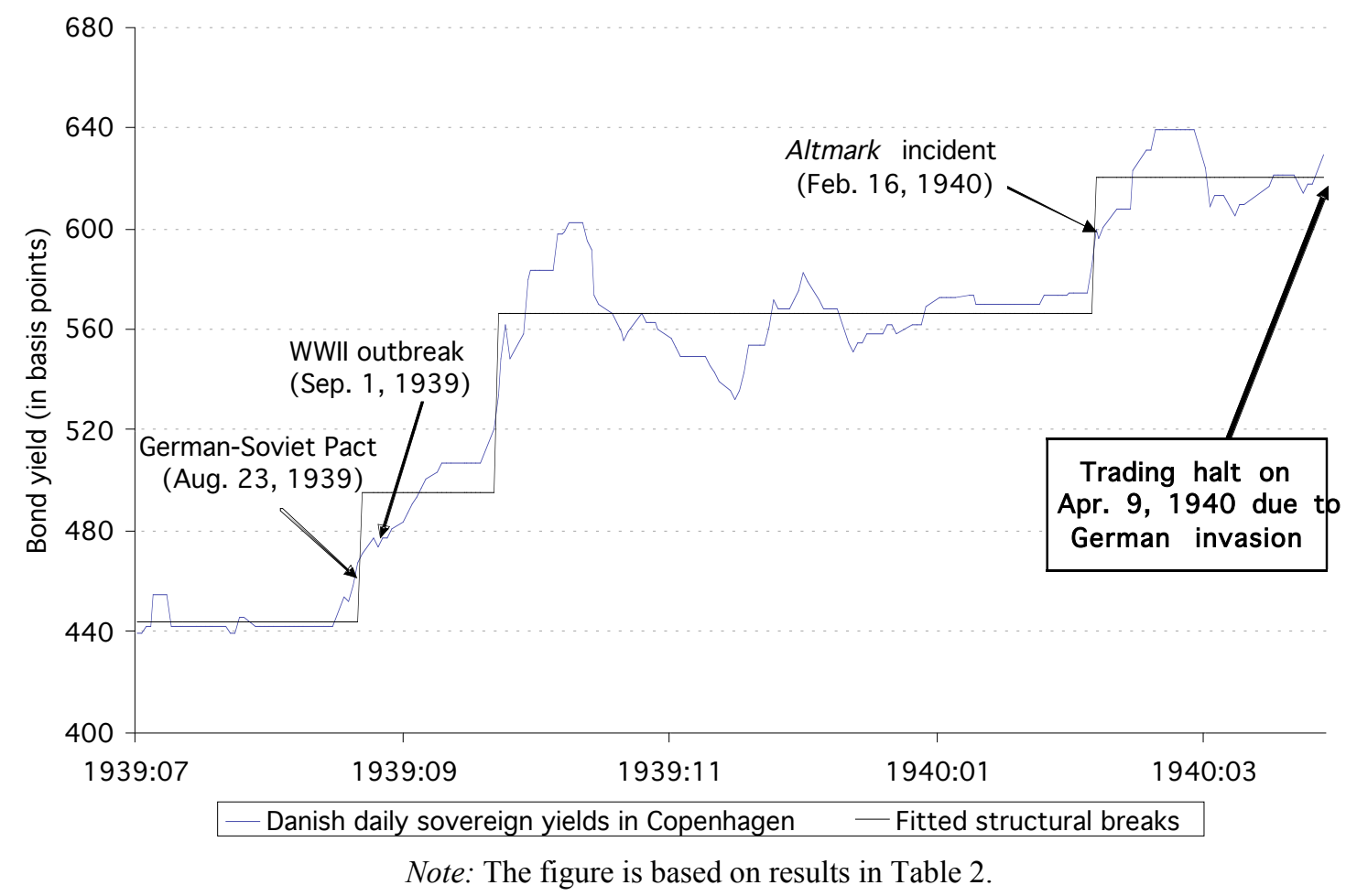

Figure 2: Danish sovereign yields and structural breaks. Copenhagen market (weekly data).

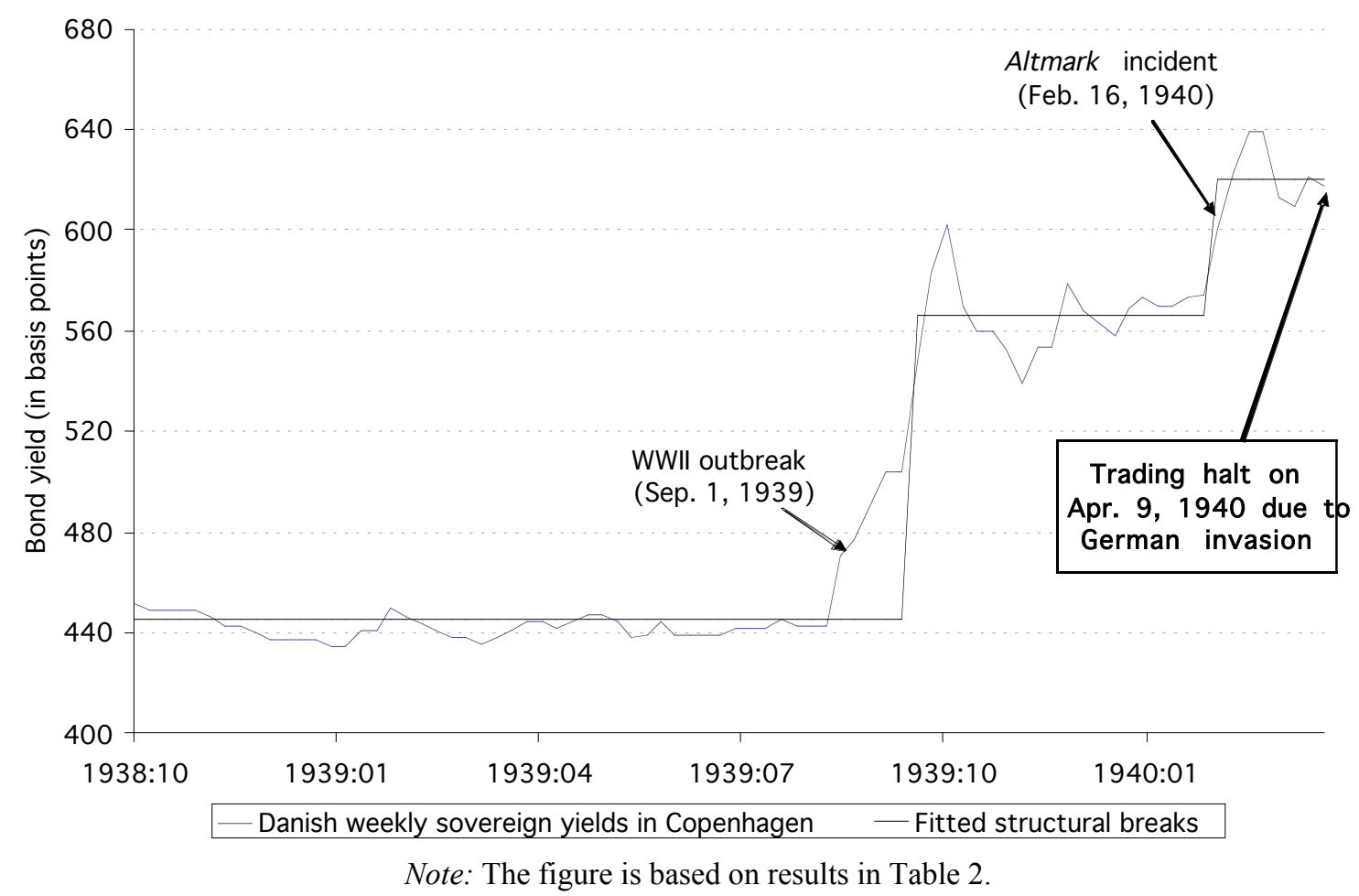


Figure 3: Danish sovereign yields and structural breaks. Stockholm market (weekly data).

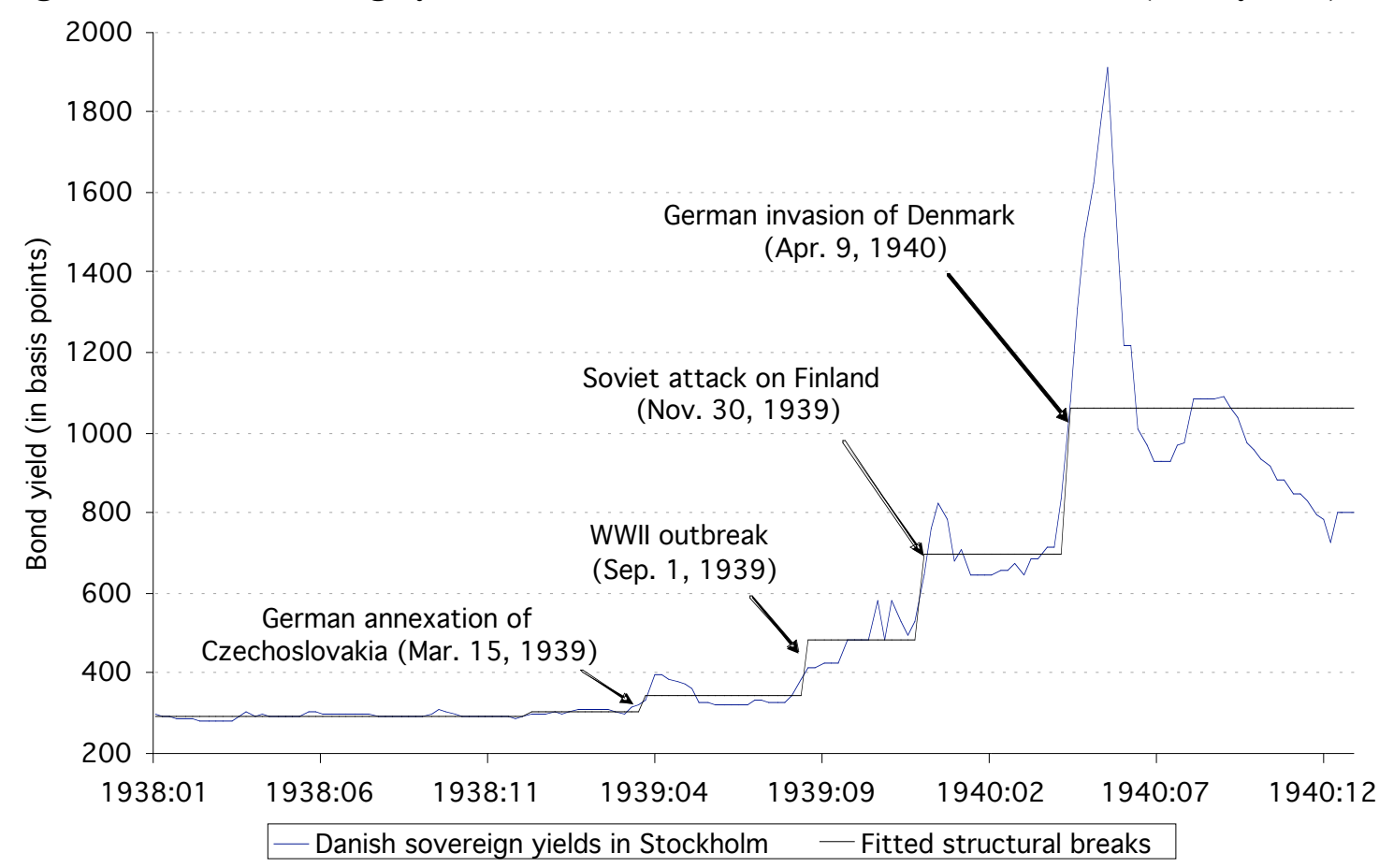

Note: The figure is based on results in Table 2.

Figure 4: Finnish sovereign yields and structural breaks. Helsinki market (daily data).

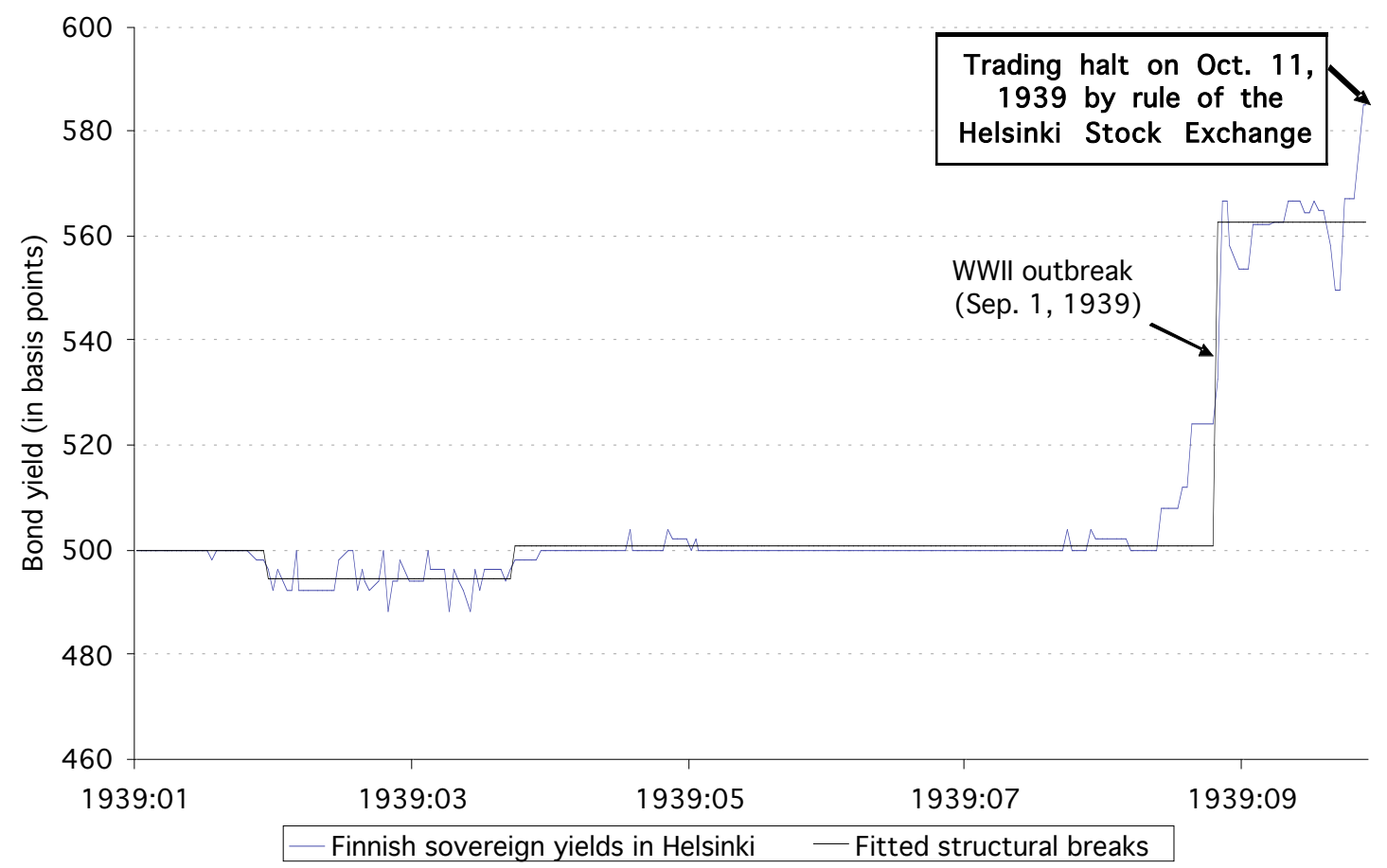

Note: The figure is based on results in Table 2. 
Figure 5: Finnish sovereign yields and structural breaks. Stockholm market (weekly data).

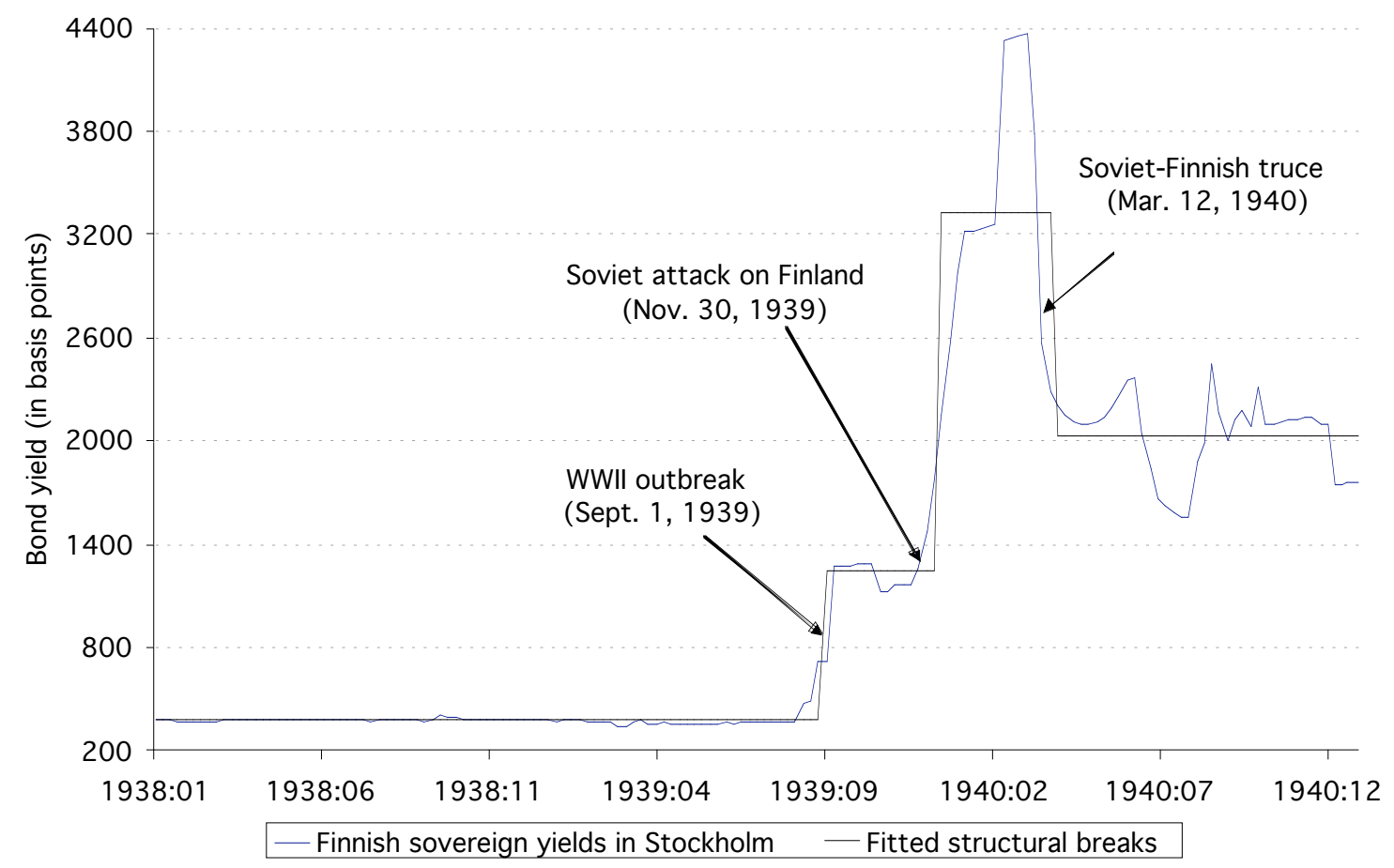

Note: The figure is based on results in Table 2.

Figure 6: Norwegian sovereign yields and structural breaks. Oslo market (daily data).

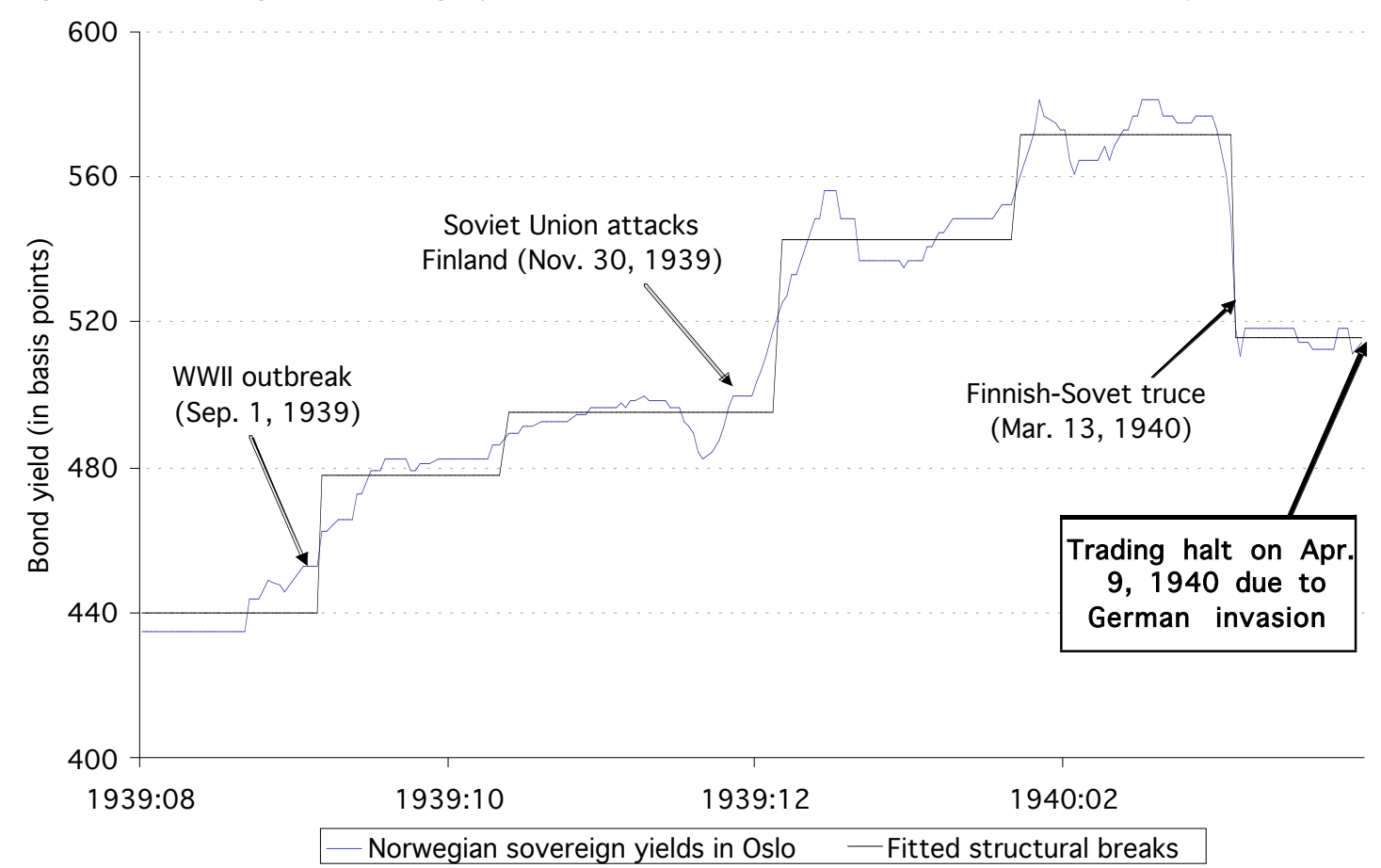

Note: The figure is based on results in Table 2. 
Figure 7: Norwegian sovereign yields and structural breaks. Stockholm market (weekly data).

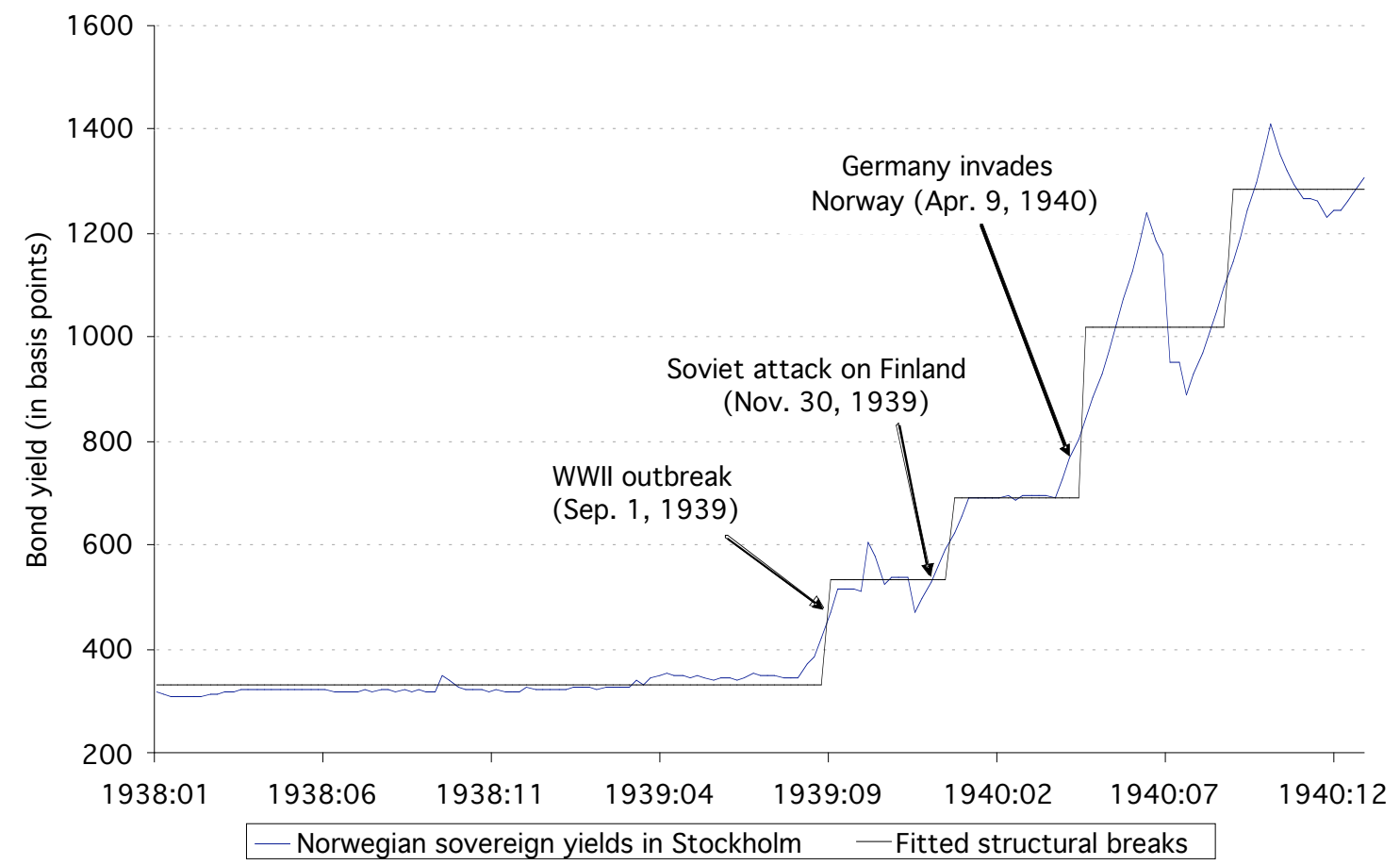

Note: The figure is based on results in Table 2.

Figure 8: Swedish sovereign yields and structural breaks. Stockholm market (weekly data).

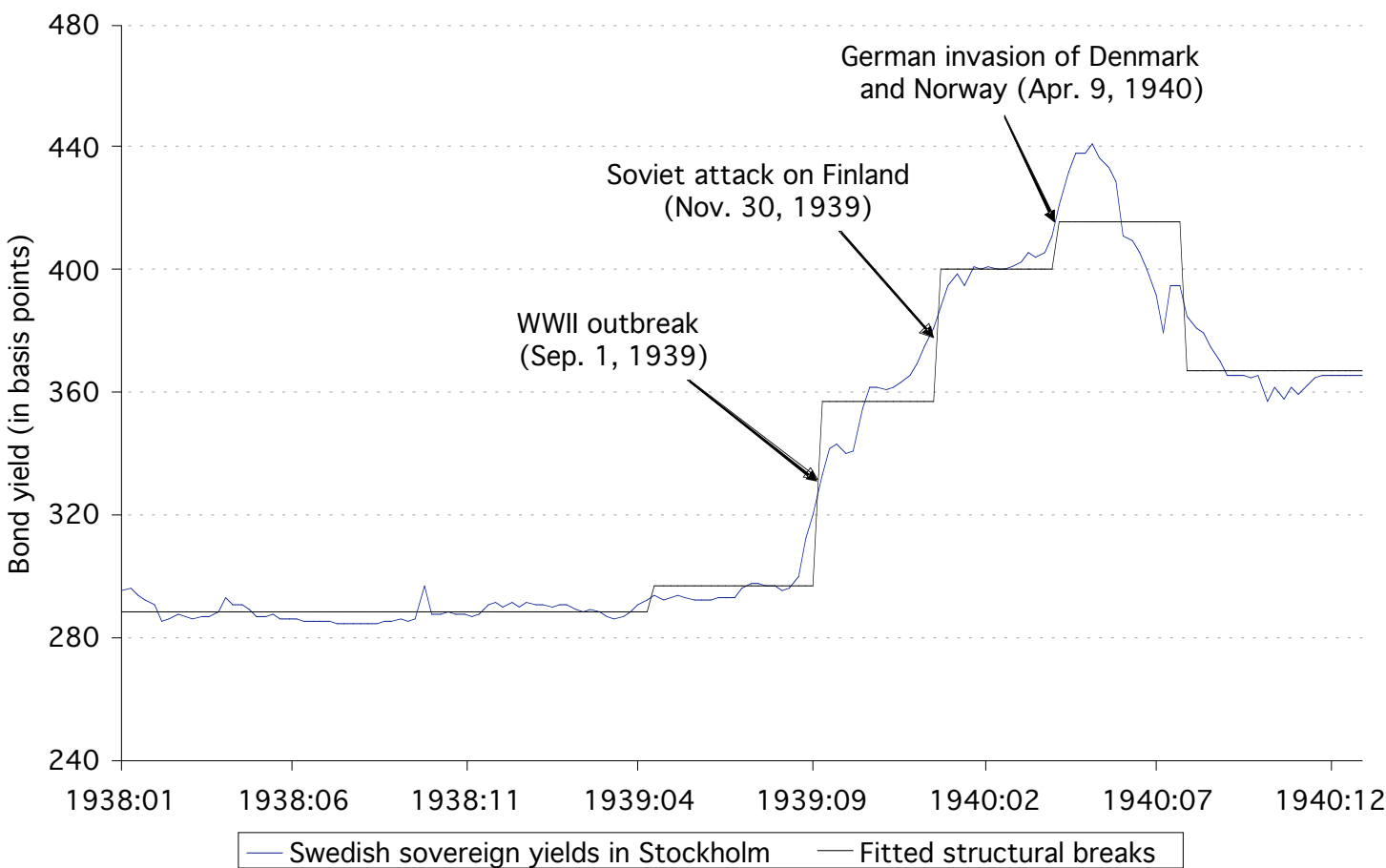

Note: The figure is based on results in Table 2. 
Figure 9: Danish sovereign spreads. Copenhagen market (monthly data).

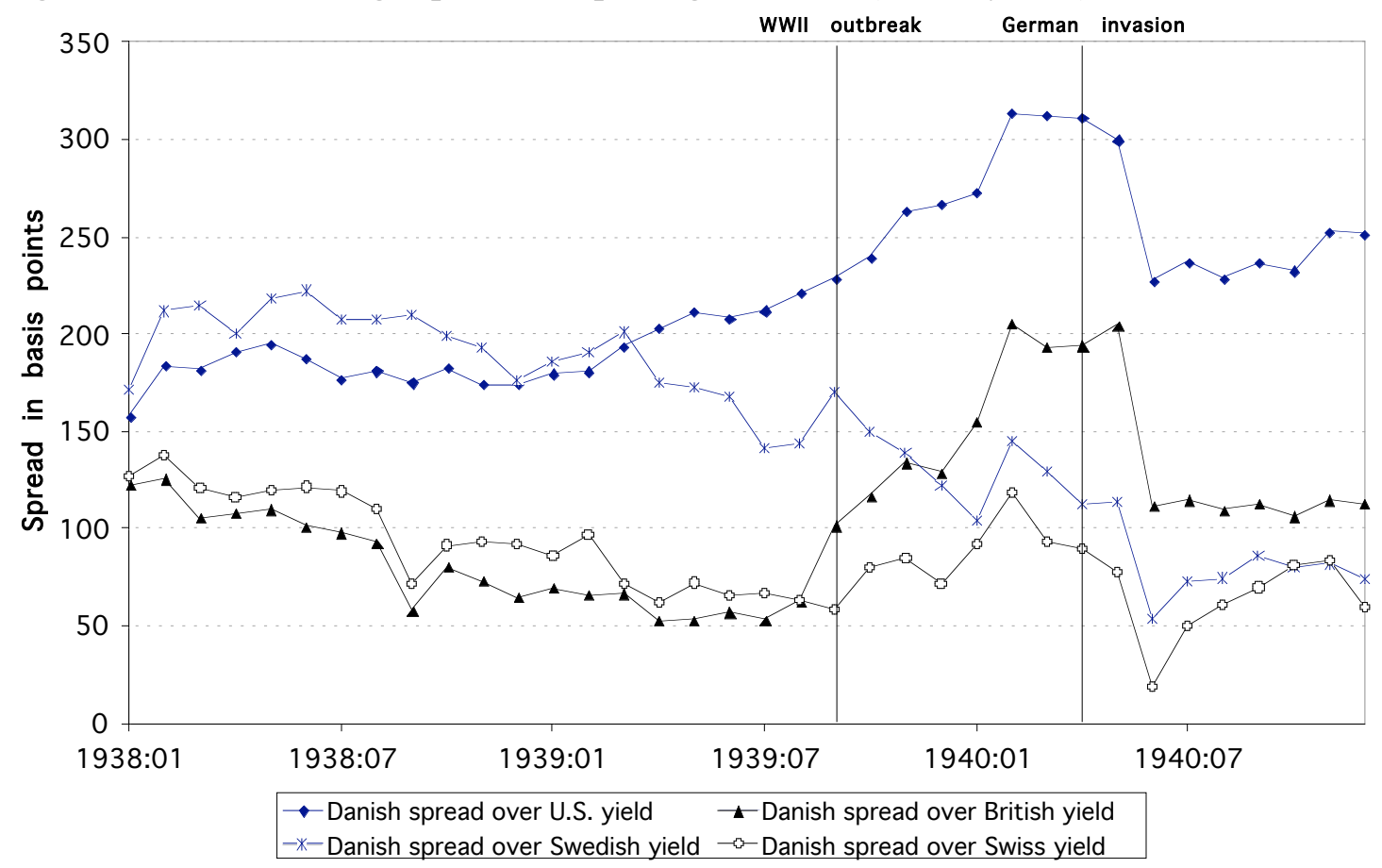

Figure 10: Norwegian sovereign spreads. Oslo market (monthly data).

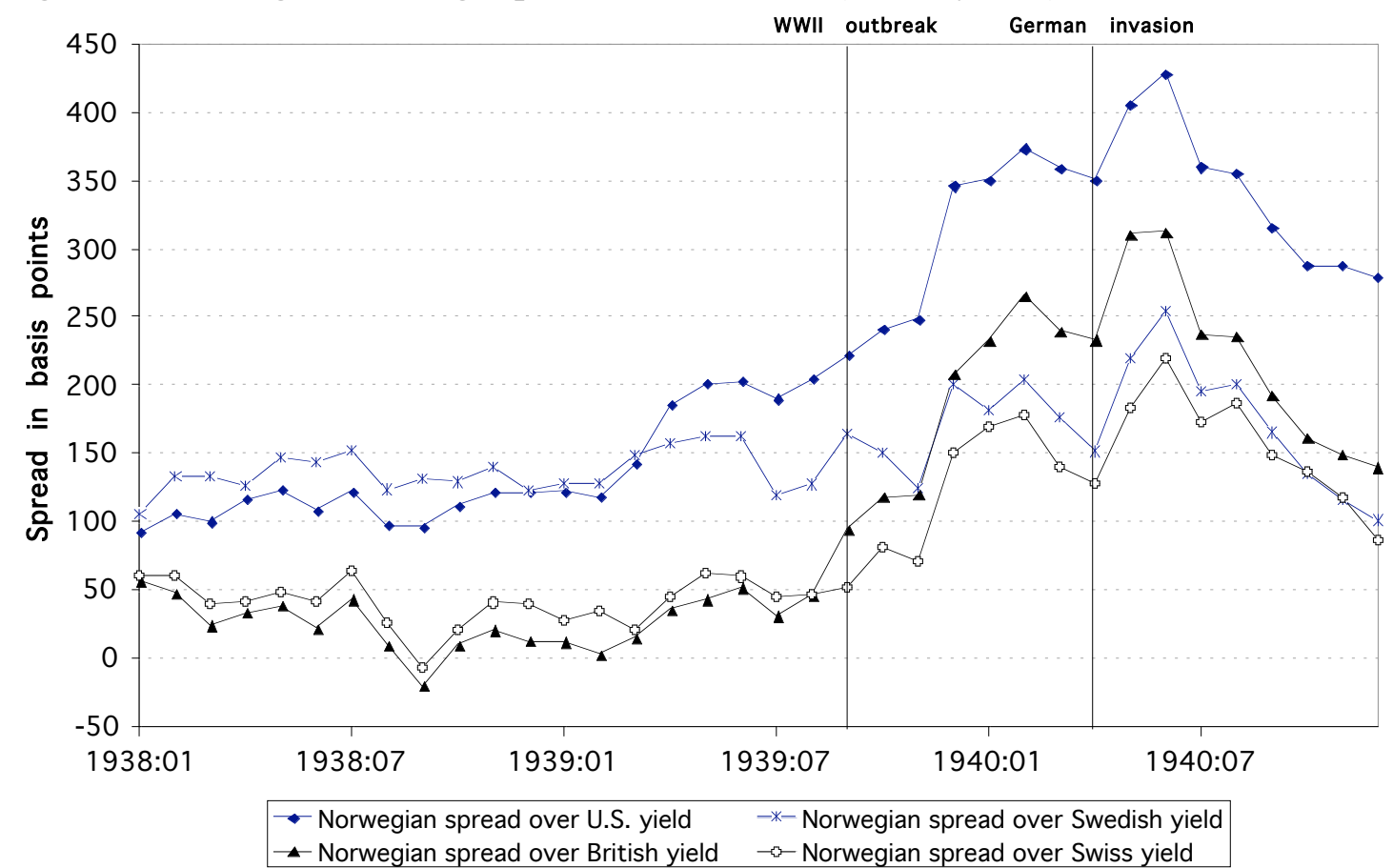

